\title{
Interações entre escrita e instrumentalidade em Ladainha e Eclusas, para violão solo
}

\author{
Ledice Fernandes de Oliveira Weiss \\ Universidade de São Paulo \\ ledicefelice@gmail.com \\ ORCID: https://orcid.org/0000-0002-4227-0485 \\ Silvio Ferraz \\ Universidade de São Paulo \\ silvioferraz@usp.br \\ ORCID: https://orcid.org/0000-0001-8263-6640
}

\begin{abstract}
Resumo: Este artigo tem como tema as estratégias de construção de performance de duas peças para violão solo, Eclusas e Ladainha, traçando um amplo diálogo com os violonistas e pesquisadores Daniel Murray e Stanley Levi, que não apenas estrearam cada qual uma das duas obras, como também deixaram registrados em trabalhos acadêmicos seu modo de construção de performances. Propomos assim uma leitura dessas duas composições a partir dos paradigmas sonoros que permeiam essas obras, do conhecimento do universo de referências do compositor (Silvio Ferraz) e do universo de performance do violão da segunda metade do séc. XX herdado pela violonista (Ledice Fernandes Weiss). Observamos a importância da composição e reconstrução do gesto nas duas pontas do processo de colaboração compositor-interprete. Nossos principais referenciais são as noções de técnica estendida e aquela do aspecto tripartite da música no gesto, textura e figura, tal qual proposto por diversos compositores, como B. Ferneyhough, H. Lachenmann, Luciano Berio e resgatada pelo compositor.
\end{abstract}

Palavras-chave: Violão, Técnica Estendida, Colaboração Criativa, Gesto Musical.

\section{Interactions between notation and instrumentality in Ladainha and Eclusas for solo guitar}

Abstract: This article has as its theme the performance construction strategies of two pieces for solo guitar, Eclusas and Ladainha, establishing a wide dialogue with the guitarists and researchers Daniel Murray and Stanley Levi, who not only premiered each of the two works, but also got to know their strategies on performance construction in academic works. Thus, we propose a reading of these two compositions based on the sound paradigms that permeate them, the knowledge of the universe of references of the composer (Silvio Ferraz) and the universe of guitar performance in the second half of the century based upon the guitarist's experience (Ledice Fernandes Weiss). We observed the importance of the composition and reconstruction of the gesture at both ends of the composer-interpreter collaboration process. Our main references are the notions of extended technique, and that of the tripartite aspect of music in gesture, texture and figure, as proposed by composers such as Brian Ferneyhough, Helmut Lachenmann, Luciano Berio and restored by the composer.

Keywords: Guitar, Extended Technique, Creative Collaboration, Musical Gesture.

O presente artigo desenvolve o trabalho apresentado no V Encontro Internacional de Teoria e Análise Musical, EITAM5 (WEISS; FERRAZ, 2019, p. 365-374). 


\section{A interpretação e a re-apropriação da escrita}

O presente trabalho trata dos processos de escrita, interpretação, re-apropriação e transmissão do material sonoro concebido por um compositor e reconstruído em performance por um intérprete instrumentista. Nesta cadeia de sucessivas traduções (do som e gesto imaginados ao som e gesto em performance), a transversalidade acontece na contribuição dada por cada ator do processo.

Sendo uma reflexão conduzida a dois por um compositor e uma violonista, o texto do artigo se apresenta na forma de um diálogo, em que a autora-violonista conduz a reflexão no corpo principal do texto, e tanto as respostas e comentários do autorcompositor com as citações de autores diversos e dos instrumentistas entrevistados, em forma de citação direta.

A fim de dar corpo à discussão, nos pautaremos no caso concreto de duas peças, Ladainha (2007-2008), para violão solo com live transforming, e Eclusas (composta em 2018, com partitura revisada publicada em 2019), para violão solo. Utilizaremos como ferramentas, além da vivência da performance, o estudo das soluções encontradas na interpretação da partitura pelos dois violonistas e pesquisadores para quem as obras foram dedicadas - respectivamente, Daniel Murray Vasconcellos e Stanley Levi Fernandes - a partir do registro em vídeo das estreias, bem como do depoimento dado em entrevistas pelo compositor e pelos intérpretes.

O objetivo do trabalho é, assim, identificar nas obras analisadas os sucessivos e transversais processos de tradução que o gesto musical imaginado sofre até atingir uma forma artística efêmera, que é a da performance, fomentando a discussão acerca da dificuldade de tradução e interpretação inerente à escrita. $\mathrm{O}$ debate insere as questões da mediação e da colaboração entre compositor e performer.

\section{Apresentação de Ladainha e Eclusas}

Compostas a um intervalo de dez anos uma da outra, as duas peças para violão solo possuem uma forte identidade musical; sua sonoridade reflete uma concepção criativa em que a ideia de afeto determina sua forma e seu material sonoro, que é fundamentado em diferentes tipos de escuta. Assim, a estrutura - bastante semelhante, de Ladainha (2007- 
2008) e de Eclusas (2018) - baseia-se na transição contrastante entre diferentes texturas violonísticas, cada uma lidando com recursos mais ou menos idiomáticos, que exploram no violão possibilidades timbrísticas das mais às menos estendidas. Ao parametrizarem os gestos do violonista e reinventarem sua técnica; ao partirem de diálogos mais ou menos intensos com seus intérpretes; ao adaptarem as ideias inicialmente concebidas propondo soluções dinâmicas imaginadas ora pelo compositor, ora pelo instrumentista; ao ampliarem a sonoridade típica do instrumento através da manipulação de sua ressonância (escordatura e microtonalismo), as duas peças para violão reciclam possibilidades de ampliação da gama de sonoridades de um instrumento tão tradicional quanto o violão.

Daniel Murray Vasconcellos, para quem Ladainha é dedicada, salienta, em sua dissertação de mestrado, a característica cambiante dessa identidade própria à obra, que passa "da sonoridade tradicional às sonoridades estendidas com alturas menos definidas", com "inclusão gradual de coeficientes de ruído", caracterizando uma "escrita cíclica entre sons tonais e ruídos" (VASCONCELLOS, p. 27). Tais características são, em realidade, reflexo de uma densa concepção da escuta musical, que por sua vez se inspira nas ideias de dois compositores europeus, Helmut Lachenmann e Brian Ferneyhough. Por conseguinte, a transição entre escutas gestual, textural e figural se traduz, em Ladainha e Eclusas, na oscilação entre sonoridades secas (rudes e percussivas), momentos de texturas em arpejos, tremolos e trinados (caracterizando sons ressonantes) e, no caso de Ladainha, na presença de motivos melódico-harmônicos ${ }^{1}$.

É de Ferneyhough que tomamos emprestada a ideia dos três níveis da escuta musical - o da figura, o da textura e o do gesto -, sendo o primeiro - relativo às relações que se estabelecem entre alturas de notas - o mais abstrato (posto que dependente de um parâmetro visual, de disposição das notas na partitura). Quanto à textura, que seria dependente de uma certa permanência do fluxo sonoro para que se caracterize enquanto tal, ela teria um aspecto igualmente subjetivo, por remeter a sensações; no entanto é isenta de uma função musical representativa, ao contrário da escuta figurativa ${ }^{2}$. No pensamento composicional presente nas duas peças, a escuta textural assume, por suas qualidades em

\footnotetext{
${ }^{1}$ Observe-se que este procedimento composicional tem um parentesco que não passa desapercebido com uma das obras mais importantes do repertório violonístico do século XX, La Espiral Eterna (1971) de Leo Brouwer.

${ }^{2}$ Um estudo mais detalhado da proposta de Brian Ferneyhough de aspectos da escuta musical foi trabalhado por Ferraz $(1997,1998)$.
} 
termos de permanência e continuidade, um importante papel estrutural para o discurso musical capaz de conectar os eventos sonoros, por mais segmentados que estejam, e atribuir-lhes poder de compreensão, efetivação e persuasão (TEIXEIRA DA SILVA; FERRAZ, 2015a, p. 120).

Por fim, o gesto, entendido em suas duas dimensões, sonora e instrumental, abre a escuta a múltiplas modalidades, que relacionam, de maneira significativa, a música ao movimento (GODØY; LEMAN, 2010, ix). Tal escuta gestual, podemos ainda relacionar a uma escuta simbólica, "resultado de um cruzamento semiótico entre dois sistemas de signos, ou entre um sistema de signos e a linguagem (gestual, visual ou verbal)" (FERRAZ; ALDROVANDI, 2000, p. 2, traduções nossas).

\begin{abstract}
Abre-se uma outra possibilidade de pensar figura, textura e gesto, agora face a este jogo de sinestesia próprio da percepção humana. É neste sentido que podemos dizer que, na figura, a imagem se faz enquanto objeto visual (os perfis melódicos, a ideia de linha melódica, de bloco harmônico, de sobreposição), na textura em objeto tátil (rugosas, lisas, densas, rarefeitas) e na kinestesis, em um fluxo de energia que pode ser refeito pelo corpo. (FERRAZ, 2021)
\end{abstract}

Nesse sentido, observa-se tanto em Ladainha com em Eclusas a contraposição de dois tipos de sonoridade: a das notas de altura definida e sons mais secos (VASCONCELLOS, 2013, p. 27). Ao referir-se a elas, o compositor descreve Ladainha:

\begin{abstract}
Existem dois tempos que andam em paralelo. O tempo das melodias longas, tempo lento, piano ou pianíssimo, tempo de um lamento. E há o tempo das trovoadas, das portas que se fecham e das cadeiras arrastadas: acordes, pizz. Bartók e fortes súbitos em movimentos mais rápidos, aflitos, angustiados e tensos que invadem o curso livre do choramingo de velhinhas entoando suas ladainhas. (VASCONCELLOS, 2013, p. 27)
\end{abstract}

Veremos abaixo como a escuta gestual nas obras estudadas relaciona-se, em grande parte, ao material mais percussivo, de sons secos, tanto pelo aspecto físico e visual da percussão ao violão como pela resultante sonora, enquanto a textural diz em geral respeito a recursos violonísticos mais enraizados (harpejos, trinados próximos e oitavados, tremolos em campanellas, tremolos de várias notas...), derivados dos grupos técnicos ponteado e rasgueado (LEVI FERNANDES. In: LEVI FERNANDES et al., 2021). 
Ademais, as duas obras possuem pontualmente momentos de escuta figural, em meio às escutas majoritariamente textural e gestual: enquanto Eclusas possui um curto trecho atipicamente melódico, que veremos abaixo, em Ladainha, trata-se especificamente da frequente reiteração de um único motivo (composto de acordes plaqués tocados de maneira forte e o mais seca possível, Figura 1), que pelo seu contorno melódico cromático descendente, pode ser visto como um elemento temático (figural) e, pela articulação voluntariamente seca de seus acordes, desperta concomitantemente as duas outras escutas.

\section{Figura 1 - Silvio Ferraz, Ladainha: motivo de acordes secos.}

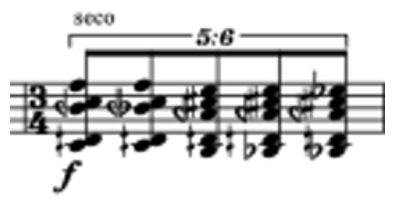

Fonte: Ferraz, 2008, p. 1.

Sobrevoando a partitura desta obra, vê-se que, nas seções inicial e final, predomina uma textura onde se alternam os dois elementos evocados por Murray - o do lamento com suas campanellas, mais piano, e o das trovoadas em fortíssimo, com seus acordes secos, seus pizzicatos Bartók e percussões sobre o tampo. Grosso modo, são intitulados "calmo e cantabile possibile" os pequenos momentos em que predomina o lamento, e "agitato" aqueles em que os gestos em forte se tornam mais presentes. Há, por momentos, uma alternância, a tal ponto frenética de nuances dinâmicas extremas, que se poderia pensar em sua serialização nota a nota (Figura 2).

Figura 2 - Silvio Ferraz, Ladainha: alternância textura ressonante e gestos secos.

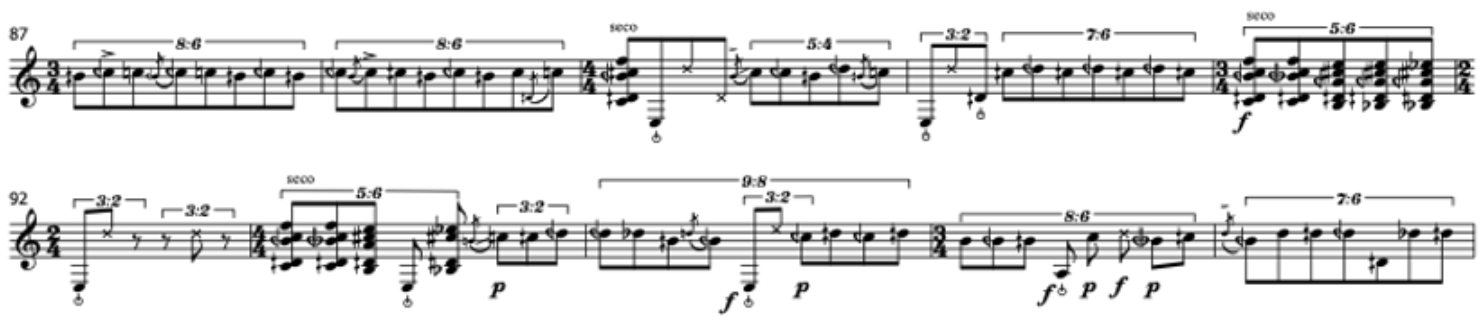

Fonte: Ferraz, 2008, p. 4. 
É crucial observar que tanto o lamento quanto os acordes secos calcam sua gestualidade na presença de microtons, obtidos graças a uma escordatura bastante singular - que é exatamente a mesma em Ladainha e Eclusas -, posto que altera a afinação de duas cordas centrais do violão, a terceira e a quarta. Essa escordatura faz uso de microtons, através da elevação de $1 / 4$ de tom d 4a corda, e o abaixamento da 3 a corda, do mesmo intervalo. Ela encontra-se explicada na Figura 3, item 2.

Figura 3 - Silvio Ferraz, Ladainha: bula.

1.

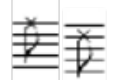

tap the guitar body board trying to produce different sounds - higher or less higher sounds.

2.

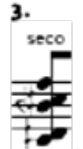

quarter tone scordattura

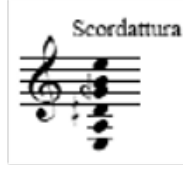

3.

except to arpegglato chords, all the other chords must be played with all notes played simultaneously and very dry.

Fonte: Ferraz, 2008, p. x.

A partir dessa escordatura, muito do lamento de Ladainha provém de uma sonoridade "desafinada", obtida a partir de longos tremolos sobre falsos uníssonos principalmente concentrados ao redor de dois polos, as notas Sol (terceira corda solta) e Si (segunda corda solta, Figura 4).

Figura 4 - Silvio Ferraz, Ladainha, compasso 37-42: tremolos ao redor dos falsos uníssonos em Sol e Si.
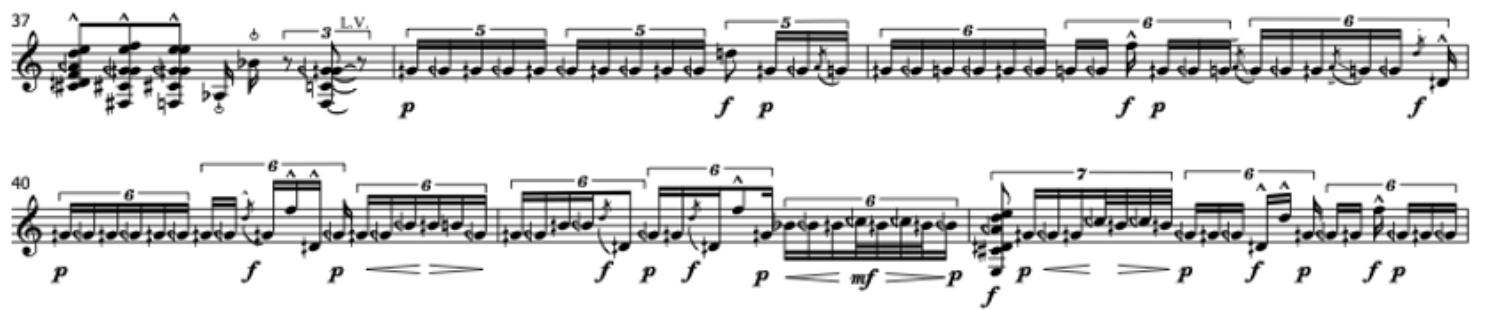

Fonte: Ferraz, 2008, p. 2. 
Notório também é que o desenrolar rítmico da peça inteira se caracteriza por certa inconstância, fazendo sucederem quiálteras sempre diferentes, por vezes aninhadas, fato que complexifica o ritmo e, notadamente, resulta para o lamento o afeto triste, de choro soluçado, com seus constantes acelerandos e desacelerandos. Esses elementos todos, aos poucos, dão forma a um tipo específico de ladainha, evocando imagens sonoras comuns no Brasil, nas músicas regionais e nos cantos de carpideiras realizando seus lamentos. Daniel Murray se recorda:

\begin{abstract}
A peça vai revelando aos poucos essa sonoridade nordestina. É como se tivesse duas músicas: o choro e umas "portas batendo" [...] essa imagem compõe uma estória que o Silvio me contava, um estímulo que me fizesse render [...]; as "portas batendo" sendo os acordes e Pizzicatos Bartók, que pontuam lá no meio. Esses acordes vão aos poucos tomando mais espaço, dominando a estrutura, e lá pelas tantas tem essa passagem bem nordestina (VASCONCELLOS, 2021).
\end{abstract}

Assim identifica-se, na estrutura geral da peça, uma seção intermediária (p. 3-4) composta de "calmo", seção de cinco compassos, onde uma textura contrapontística a duas vozes vem romper a ladainha, e de "marcato il ritmo", parte de 21 compassos caracterizada pela sucessão de aglomerados de notas inusitadamente ressonantes (lasciare vibrare), tocados em registro forte, soando como campanellas-clusters (Figura 5). Tal referência a sinos compõe importante referência, lado a lado com os lamentos e cantos populares, no repertório do violão no séc. XX. Nesse sentido, poderíamos aqui relacionar tais aglomerados com os clusters de meios-tons de La Espiral Eterna de Leo Brouwer. Ainda no que diz respeito a essa imagem de lamento, a seção explora, assim, a sonoridade de sino (campanella) - um efeito de ressonância obtido pela ação de ambas as mãos (KREUTZ, 2014, p. 122-125) tocando notas próximas em cordas adjacentes que, nas campanellas-clusters em Ladainha, têm a ressonância potencializada pelos microtons oriundos da escordatura.

Esses quase-acordes (que serão retomados em Eclusas) se destacam, ainda, por serem compostos de duas ou mais notas que formam um falso uníssono (ou uma falsa oitava): na maioria, eles rodeiam as cordas 3 e 4, ambas alteradas em um quarto de tom segundo a escordatura descrita na Figura 3, e eventualmente ultrapassam intencionalmente o marco do semitom, o que tem sempre o propósito de uma sonoridade 
instável, marcada por flutuações de batimentos. Esses aglomerados são em geral homofônicos, ritmicamente marcados, podendo também aparecer como reverberações ou cadeias de apogiaturas de notas que se encadeiam (Figura 5).

Figura 5 - Silvio Ferraz, Ladainha, "marcato il ritmo": aglomerados ressonantes.

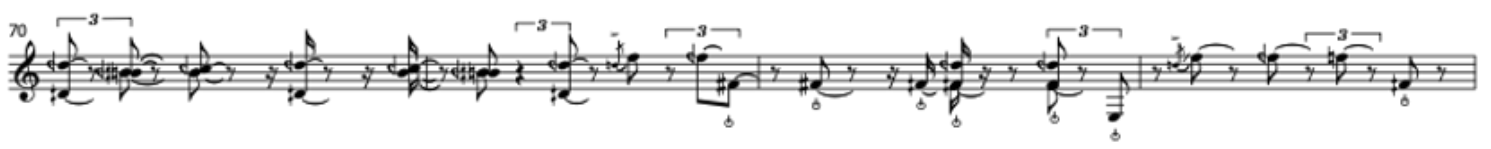

Fonte: Ferraz, 2008, p. 4.

Nas passagens alternando pizzicatos Bartók e acordes (quase sempre secos, à exceção do final de "marcato il ritmo") - compassos 25, 36-37, 47-49, 91-93, 101-102 , "a sonoridade muda muito se o violonista toca em versão solo ou em versão com eletrônica $^{3}$, a primeira sendo no geral muito mais silenciosa e rápida, enquanto que na interação com as multiplicações que a eletrônica traz, os silêncios são preenchidos por sons que conectam" (VASCONCELLOS, 2021) e que acabam alongando a peça.

Enquanto admite que o final de Ladainha propõe uma "volta" ao começo, sendo um "possível A-B-A", Murray opina que o compositor, ao escrever para violão, tenha querido salientar tanto em Ladainha como em Eclusas a característica intimista do instrumento, explorando o registro piano (VASCONCELLOS, 2021). No entanto, a presença do componente eletrônico em Ladainha, que retoma, retransmite e modifica os sons tocados ao vivo pelo violão, vem ainda a complexificar a relação entre escrita e performance.

Havia a eletrônica, o lamento e os golpes como batidas na segunda parte: isto é o que trabalhamos no limite também de coisas que eu tinha escrito e que no momento pareciam inalcançáveis. (FERRAZ, 2021)

$\mathrm{Na}$ estreia, foi o próprio compositor quem manipulou a eletrônica; Daniel ainda a tocou diversas outras vezes, com e sem eletrônica, e até com a eletrônica pré-gravada, mas nunca mais até o presente em duo com o compositor. Segundo o intérprete, eles

\footnotetext{
${ }^{3}$ Segundo Murray, o compositor lhe deixou a escolha de fazer a peça em diferentes versões, para que pudesse se adaptar a diferentes situações de concerto.
} 
aproveitaram dessa ocasião para explorar um registro diferente da obra, tocando-a muito mais forte do que haviam trabalhado.

\begin{abstract}
No dia da estreia teve aquela vontade de eletrônica, e ficou exatamente o oposto dessa coisa mais fofoca, intimista, esse choro que não se escuta direito, pois tudo foi amplificado, multiplicado pela eletrônica no fundo da sala... foi uma experiência interessante. Em princípio a eletrônica teria que ser mais baixinha. Essa peça tem uma gama de possíveis interpretações [...] e essa que a gente fez lá na USP foi a mais barulhenta, tinha uma eletrônica "pra quebrar", e o violão era bem presente, bem amplificado. (VASCONCELLOS, 2021)
\end{abstract}

Enquanto a aproximação de Ladainha em seu aspecto arquitetural, de compreensão das diferentes partes e afetos foi algo, para Daniel Murray, menos da ordem da leitura do que da vivência, tal não foi o caso do processo de Stanley Levi Fernandes com a partitura de Eclusas, que lhe veio às mãos já pronta. Daniel não teve contato com uma partitura pronta, mas acompanhou seu processo de concepção a partir de pedaços que iam se modificando e agregando aos poucos, até comporem a peça tal qual estreou em maio de 2008.

\footnotetext{
O músico, quando aborda pela primeira vez Ladainha, Eclusas ou qualquer outra partitura, não se deve deixar levar por uma tendência a escanear a partitura "da esquerda pra direita", mas sim adotar uma técnica de decifração, primeiro buscando uma visão geral da partitura, pra depois entrar nos detalhes, como nos ensina Brian Ferneyhough. (FERRAZ, 2021)
}

Stanley Levi Fernandes comenta a complexidade inerente à escrita de Eclusas, que não seria "simples nem óbvia". O violonista declara ter se aproximado da obra, como sempre faz, com uma visão analítica “em vários níveis: partindo do nível macro, para ver as grandes seções da peça, e em seguida ir descendo paulatinamente nas subdivisões, até atingir o nível dos motivos, frases, e da nota individual" (LEVI FERNANDES. In: LEVI FERNANDES et al., 2021).

O violonista identifica a primeira grande seção de Eclusas (p. 1-2), onde há a exposição de um motivo inicial (Figura 6), “com essa técnica que o Silvio criou com as pestanas deslizantes" (sendo que esta seria para Levi a primeira frase), motivo que aos poucos se entrelaça com "novos elementos, notas e pequenos gestos". A segunda e última grande seção iniciaria, para Stanley Levi, no último pentagrama da pagina 2 (tempo 1): 
"uma longa seção de tremolos, em que começam a aparecer apogiaturas intercaladas".

Dentre as partes que compõem esta última seção, o violonista destaca uma que contém taps, glissandos, scraps, pizzicatos Bartóks, tappings (p. 3, linhas 2 e 3) e, em seguida, o "fluido e cantabile, que para mim é uma coisa mais melódica e sentimental, que eu entendi como um climax da peça" (Figura 7) (LEVI FERNANDES. In: LEVI FERNANDES et al., 2021). A compreensão do significado e função desta parte contrastante é um dos pontos cruciais que revelam divergências e pontos de vista diametralmente opostos, estando originalmente longe de uma concepção sintática e romântica da música.

Em minha música, não há melodia principal, nem tema, nem motivo; o que aparece nela são objetos... São golpes, gestos que deveriam ser realizados entre muitas cordas, para justamente criar a reverberação entre elas, como nos golpes de sinos. (FERRAZ, 2021)

Figura 6 - Silvio Ferraz, Eclusas, p. 1, linha 1: motivo inicial.

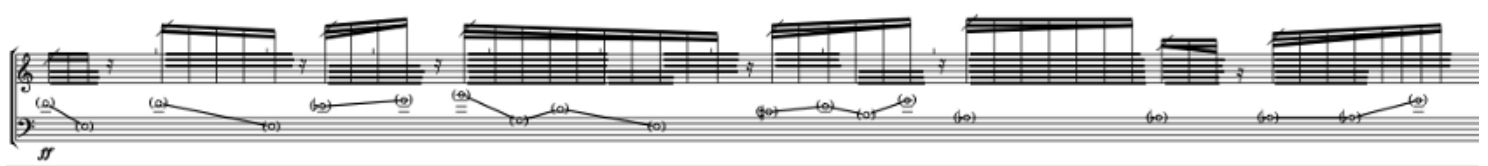

Fonte: Ferraz, 2019, p. 1.

Figura 7 - Silvio Ferraz, Eclusas, p. 3, linhas 1-3: Tempo 1 e fluido e cantábile.
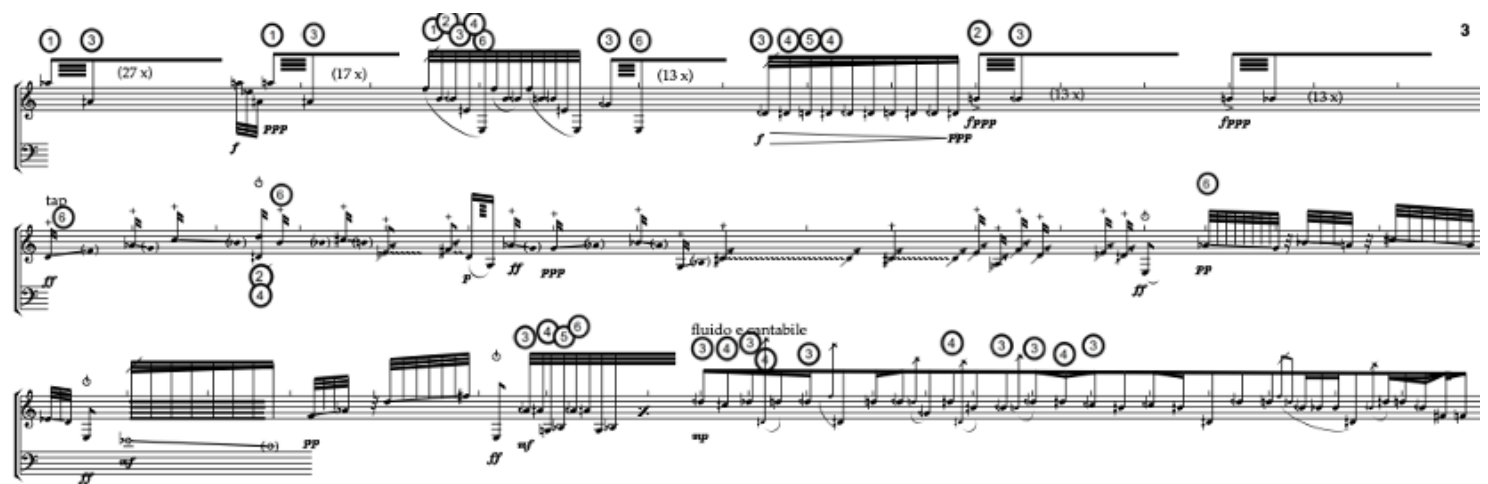

Fonte: Ferraz, 2019, p. 3. 
Da mesma forma, na realização da passagem, Stanley Levi procurou realçar o aspecto melódico e figural, mantendo a linha melódica o máximo possível em uma só corda, o que acarretou em "dedilhados horríveis pra mão esquerda" (LEVI FERNANDES. In: LEVI FERNANDES et al., 2021), enquanto a própria partitura indicava cordas específicas para cada nota, a fim de criar gestos de bariolage.

Acrescentemos que o final de "fluido e cantabile" se demarca pela inserção gradual de elementos percussivos, introduzindo aquilo que, a partir das três últimas linhas, seria para nós uma última seção de Eclusas. Ela caracteriza um retorno a uma escuta textural e gestual (Figura 8), retomando elementos da primeira seção (arpejos, trinados, aglomerados fortes de falsos uníssonos, percussões diversas sobre o tampo) e do Tempo 1 (tremolos e glissandos de finger tap $)^{4}$. Embora a análise formal que propõe Levi não se baseie pura e simplesmente na classificação em grupos técnicos ${ }^{5}$ dos gestos instrumentais de Eclusas, ele considera que esse estudo permite a compreensão de "um caráter, uma atmosfera" das distintas partes da obra (LEVI FERNANDES. In: LEVI FERNANDES et al., 2021).

Figura 8 - Silvio Ferraz, Eclusas, linha 5: percussão com dedos pronissupinados, pizz. Bartók, tremolos de 2, 3 ou 4 notas, arpejos e percussão com 4 dedos cerrados na parte inferior do tampo.

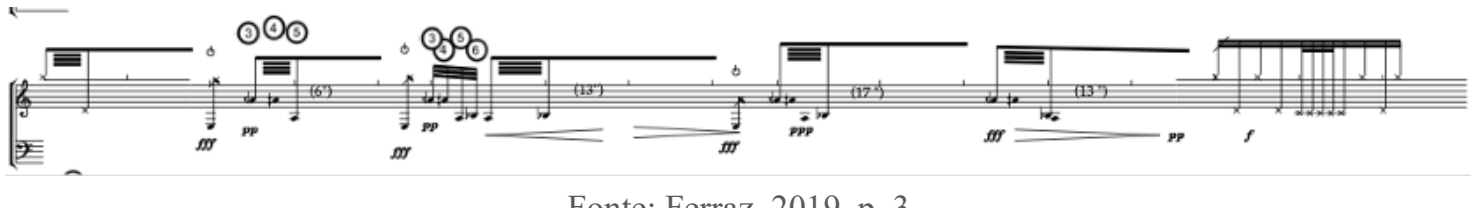

Fonte: Ferraz, 2019, p. 3.

Assim, a passagem de fluido e cantabile, onde a técnica ponteado, a sonoridade legato e a escuta figural reinam, ao progressivo retorno de elementos secos e tremulados (tremolos e trinados em ponteado, mas também nas diferentes formas de percussão), reintroduz um fluxo musical textural, sensorial e contínuo, que Levi percebe assim:

\footnotetext{
${ }^{4}$ Detemo-nos sobre cada um desses gestos instrumentais na seção "No violão", apresentada a seguir.

${ }^{5}$ Abaixo veremos que Stanley Levi Fernandes propõe, em suas pesquisas acadêmicas, a abordagem dos gestos violonísticos em grupos técnicos.
} 
A escrita dele é uma escrita constante, e a impressão que eu tenho é que são metamorfoses de materiais em níveis variados, e particularmente num nível micro. Tem frases ali em que você tem uma sucessão de gestos que pertencem a famílias de gestos muito diferentes. Tem um harpejo, um Bartók, uma batida... e isso justaposto em uma sucessão meio frenética, mas esse frenesi também caracteriza uma seção (LEVI FERNANDES. In: LEVI FERNANDES et al., 2021).

As semelhanças entre ambas as peças é notória, tanto com relação aos três tipos de escuta que ocupam o pensamento composicional empregado, mas também em termos de material musical (a presença dos aglomerados de falsos uníssonos em fortíssimo, as texturas em ponteado, a forte presença de pizzicatos Bartók e outras percussões no tampo do instrumento), como ainda na forma geral, em que uma parte central se destaca por alguma particularidade, e é inserida entre um inicio e um fim em que predomina a escuta textural.

A última frase (lento ma sempre fff) reitera e reverbera o gesto dos aglomerados homofônicos de notas (Figura 9), que havia sido primeiramente empregado na Ladainha, e que aparecera durante toda a parte inicial de Eclusas, desde o fim da página 1. Mesmo se valendo da mesma escordatura nas duas obras, os aglomerados não são em nenhum exemplo os mesmos; em Eclusas, eles se concentram sobre dois falsos uníssonos: ora sobre a nota Ré da quarta corda solta do violão, que na bula é mencionado como um "tricorde" empregando a sexta, a quinta e a quarta $\operatorname{cordas}^{6}$, ora sobre a nota La, uma oitava acima da quinta corda solta, que deve ser tocado entre as cordas 3 e $5^{7}$.

Figura 9 - Silvio Ferraz, Eclusas, última linha.

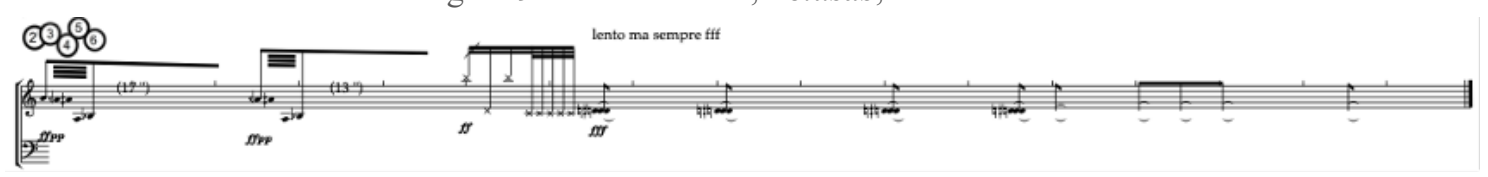

Fonte: Ferraz, 2019, p. 3.

\footnotetext{
${ }^{6}$ Ou seja, composto de dois Rés justos (cordas 5 e 6 ) e um elevado de $1 / 4$ de tom.

${ }^{7}$ Composto de um La justo (corda 5), um elevado de $1 / 4$ de tom (corda 4) e um abaixado de $1 / 4$ de tom (corda 3).
} 
“Os acordes de sinos (que me remetem à imagem de uma música nordestina desafinada, tocada na rabeca) são iguais entre Eclusas e Ladainha" (FERRAZ, 2021). Por outro lado, na parte central de Ladainha, o aglomerado aparecia sob duas formas (Figura 5, acima): ora constituindo um tricorde sobre a nota $\mathrm{Si}$ da segunda corda solta em falso uníssono ( $\mathrm{Si}$, Si elevado de um quarto de tom, Si abaixado de um quarto de tom ${ }^{8}$ ), ora constituindo uma falsa oitava entre as notas Ré da quarta corda elevada de um quarto de tom e sua oitava, realizada necessariamente sobre a terceira corda, abaixada de um quarto de tom ${ }^{9}$. Enfim, em Eclusas há, na página 2, final da quarta linha, a aparição do tricorde em La, reiterado quatro vezes, e que excepcionalmente abandona o padrão em fortissimo, devendo ser tocado em pianissimo.

Vale dizer que a exequibilidade dos tricordes de Eclusas deu margem a discussões entre os autores do presente artigo. Ao verificarmos juntos que a extensão exigida para se fazerem os três Las, nenhum deles sendo uma corda solta, não era possível para a mão esquerda em uma situação normal, a solução que encontramos, e que foi acatada pelo compositor, foi a de realizar o La da quinta corda em harmônico oitavado na 12a casa, e os outros dois, nas cordas 4 e 3. Após essa troca, ocorrida em 2019 (mais de seis meses após a estreia de Eclusas), a partitura foi revisada, incorporando a notação com o harmônico (Figura 10). Stanley Levi, ao contrário, que por ocasião da estreia também se deparou com o tricorde impossível de ser feito tal como escrito, optou por realizá-lo apenas nas cordas 3 e 4 . Refletindo sobre a solução que encontramos a posteriori, de fazer uma das três notas em harmônico, ele declarou ter preservado "uma coisa que era mais importante do que a frequência da nota, que seria nesse caso o timbre e a dinâmica". As três cordas que a partitura pedia, especialmente na parte intitulada "drunk", deveriam, a seu ver, "soar um negocio mais forte", e o harmônico poderia "prejudicar ter um ângulo [na mão direita] bom pra tocar as cordas ao mesmo tempo que o harmônico" (LEVI FERNANDES. In: LEVI FERNANDES et al., 2021).

\footnotetext{
${ }^{8} \mathrm{O}$ falso uníssono de Si é trabalhado em Ladainha igualmente sob a forma textural, em tremolos que alargam o âmbito desse intervalo dissonante para entre o Si bemol abaixado em um quarto de tom ao Ré, compreendendo ao todo uma terça quase aumentada.

${ }^{9}$ A falsa oitava em Ré de Ladainha é citada na parte intermediária (Tempo 1) de Eclusas sob a forma de tremolos de duas e de três notas, mas gestualmente não cumpre a mesma função.
} 


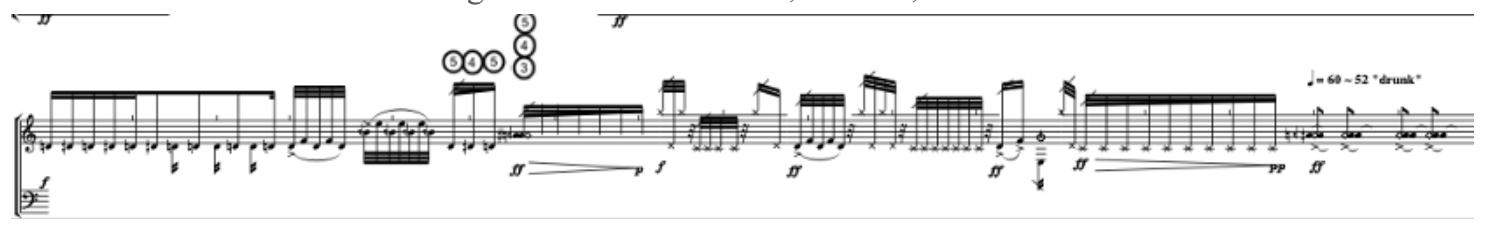

Fonte: Ferraz, 2019, p. 2.

Ritmicamente, enquanto Ladainha possuía compassos delimitados, fórmulas de compassos que se sucediam (2/4, 3/4, 4/4 e 5/4), inúmeras quiálteras e algumas aninhadas, configurando uma organização rítmica precisa, Eclusas não possui nenhuma barra nem fórmula de compasso, e deixa as relações rítmicas menos precisas, sugeridas apenas pelas figuras empregadas, pelos pequenos traços verticais sobre a partitura que orientam a contagem de alguma medida de tempo, como se via na Figura 7, pelas indicações de quantas vezes se repetem (ou por quantos segundos) os tremolos que marcam o inicio de Tempo 1 e pelo comprimento gráfico de cada gesto do motivo inicial (Figura 6).

Eclusas desenvolve de forma mais contundente que Ladainha a ideia de serialização de gestos, particularmente na combinação de gestos percussivos (feitos seja pela mão direita, seja pela esquerda) com diferentes tipos de glissando com os dedos da mão esquerda; tal é o caso dos gestos requeridos no motivo inicial da Figura 6. Acresce que, dentre as numerosas técnicas de percussão introduzidas por Eclusas, a menos usual é esta, em que a mão direita percute com a ponta de quatro dedos cerrados e estendidos em um movimento perpendicular à superfície do violão, ora sobre o tampo, ora sobre as cordas. "Em Eclusas, muitas coisas vêm da parte intermediária da Ladainha; a única coisa nova nas Eclusas é o começo - a percussão, esse tamborilar em torno das cordas" (FERRAZ, 2021).

\section{A noção de gesto musical}

$\mathrm{Na}$ época em que eu estava compondo Eclusas, quebrou o braço do violão. Ainda assim, testei cada gesto que ia inventando no violão quebrado, no violino, no violoncelo... Tentando colocar os dedos, inventar a digitação. (FERRAZ, 2021) 
Ao colocar-se no lugar do intérprete e investigar a mecânica do instrumento, o compositor cria e testa fisicamente ao violão formas renovadas do jogo instrumental, adotando uma visão corporificada do compositor (WEISS, 2019). Como Luciano Berio, opta por vislumbrar o ato compositivo como uma "construção por gestos" (TEIXEIRA DA SILVA; FERRAZ, 2015a, p. 124), acreditando ser a compreensão com o corpo, e não apenas "com o espírito e o intelecto" (PEREIRA, 2010, p. 4), e a experimentação de gestos importantes ferramentas de criação, aprendizagem e prática (GIACCO, 2016, p. $74)$.

\footnotetext{
É no instrumento que acontece a música, nem no som, nem na nota, mas no fluxo de energia que atravessa os corpos (instrumentista, instrumento, ouvinte). Os corpos na ideia de gesto:

- corpo do instrumentista (a presença do instrumentista seja atuando sobre o instrumento, seja como corpo paralelo).

- corpo do instrumento (visualidade): todo instrumento e instrumentista tem um corpo visível que participa da escuta. (FERRAZ, 2018)
}

Como no pensamento de Lachenmann, adotam-se na escrita musical as "ações mecânicas e físicas" do instrumentista como campo de atuação no processo de compor, procurando extrair do instrumento sonoridades que também nasçam de um certo embate entre a "força física mecânica" do instrumentista e a "resistência material oferecida pelo instrumento" (KAFEJIAN; FERRAZ, 2017, p 200-201); e como Ferneyhough, utiliza o próprio "índice de atividade do instrumentista" como parâmetro de definição do gesto sonoro e instrumental.

É importante manter em mente que a concepção gestual nesses casos, se inspirando nos escritos e na obra de compositores de a partir dos anos 1970, diz respeito a uma qualidade visual e cinética da música, mas reflete-se também no som e na escuta, posto que, nessa concepção, o próprio "envelope de energia do gesto corresponde, não parcialmente mas em sua totalidade, à forma do som" (LIDOV, 2006, p. 28). Nesse sentido, a composição corporificada pode vir a gerar gestos instrumentais estendidos e a produzir sons estendidos, sem no entanto que isso se torne uma meta em si.

De fato, mais do que a busca por extensões técnicas, o que mais determina as sonoridades inusitadas das duas obras é a própria reflexão sobre os tipos de escuta de que falamos acima. Poderíamos inclusive dizer que ele, como Berio, procura trabalhar "com 
os afastamentos e aproximações de sonoridades 'tradicionais' para criar estímulos na escuta” (TEIXEIRA DA SILVA; FERRAZ, 2015a, p. 124).

Quanto ao jogo instrumental, observa-se que a maior parte dos gestos instrumentais recriados no violão fazem parte do repertório gestual consagrado do instrumento, ou se valem dele. Ladainha, por exemplo, utiliza técnicas totalmente familiares ao violonista habituado ao repertório dos séculos XX e XXI ou, como se diz, "tem muita coisa na peça dele que são notas" (LEVI FERNANDES. In: LEVI FERNANDES et al., 2021). De modo a buscar uma definição do que é chamado, muitas vezes de modo inconsistente, por técnica estendida, é importante distinguirmos três elementos presentes na radicalização dessa estratégica composicional, sobretudo a partir dos anos 1970: a permutação dos modos de jogo instrumental, a parametrização da interface e a corporificação do pensamento compositivo, que conferem ao discurso musical sua singularidade. Com efeito, os gestos instrumentais imaginados pelo compositor, mais do que inovadores, partem de um funcionamento parametrizado e serializado, através da "livre combinação de modos de jogo e gesto díspares", exigindo do instrumentista "prontidão para alternar rapidamente modalidades de uso e criar elementos gestuais e expressivos que se combinam de maneira imprevisível” (PADOVANI; FERRAZ, 2011, p. 24).

Técnica estendida é diferente de "efeito instrumental"... Veja o exemplo de Gesti, de Luciano Berio: nela, partituras diferentes são feitas para o ataque da boca e para o dedilhar... existe uma serialização nisso. Se eu crio uma série de parâmetros gestuais, se eu não estou correndo atrás de uma sonoridade (pois no caso de Lachenmann, ele está correndo atrás da sonoridade), se eu estou separando e serializando os gestos, estou criando uma técnica estendida pensada como parametrização da técnica, diferente de extensão do instrumento ou extensão da sonoridade. (FERRAZ, 2021)

Procurando imaginar formas de parametrizar e serializar no violão ("separar unha e polpa do dedo, por exemplo"), citamos outro modelo inspirador, o do manual técnico para contrabaixo de Jean Pierre Robert, onde o contrabaixista se interessa a todos os possíveis tipos de ações instrumentais que aparecem no contrabaixo em músicas contemporâneas, e cria um quadro sinótico de dedilhados e efeitos instrumentais, que vem a ser uma verdadeira cartilha, destinada a compositores e contrabaixistas (ROBERT, 1992, p. 6). Essa catalogação é dividida em numerosos capítulos, cada um relatando tipos de ações de cada mão do contrabaixista no instrumento. Nesse extenso catálogo, um 
verdadeiro exemplo do pensamento serial aplicado à técnica instrumental, cada capitulo é dissecado em inúmeras combinações de ações instrumentais, em francês comumente chamadas modos de jogo e se desdobra em sub-capítulos, cada qual descrito em termos de ação instrumental e efeito; cada ação especifica é enfim explicada ao longo do livro sob a forma de um verbete. Além de descrever a ação propriamente dita, a localização exata em que ela se realiza no instrumento, o verbete também informa brevemente a amplitude dinâmica do efeito e, em alguns casos, caraterísticas do som produzido.

É, enfim, a partir da convivência desses dois paradigmas que aqui chamaremos de um paradigma da música serial e um paradigma da música "dos sons" - que surge uma terceira aproximação, resultante das exigências em termos de performance e técnica instrumental das duas tendências anteriores. Ora construindo melodias, motivos e sequências a partir da permutação de materiais composicionais e articulações instrumentais diversos e ora buscando novas sonoridades como multifônicos ou sons microtonais a partir de instrumentos tradicionais, surge assim uma aproximação composicional fortemente voltada à mecânica instrumental e às possibilidades gestuais do instrumentista. É nesse contexto, enfim, que nascem estudos de aplicação e desenvolvimento sistemático das técnicas estendidas na criação musical e na performance (PADOVANI; FERRAZ, 2011, p. 26).

Em Eclusas, a síntese de gestos é visível em três elementos descritos na bula: o primeiro, como já mencionamos acima, se observa na Figura 6, e consiste em realizar com a mão direita um tipo de percussão não usual ("percutir com pontas dos dedos cerrados da mão direita sobre cordas indicadas"), enquanto a mão esquerda faz glissandos de pestana percorrendo quase toda a extensão da escala. Vale observar que o efeito sonoro obtido, ao contrário do que pede a partitura (ff), é bastante discreto, tanto por serem pestanas a realizarem glissandos, como pelo gesto percussivo ser feito com as pontas dos dedos, atingindo uma área muito pequena das cordas. Com efeito, Murray manifestara, em um comentário que citamos acima, a impressão de que ambas as peças, Ladainha e Eclusas, possuíam um registro piano.

Quanto ao desequilíbrio dinâmico que o gesto percussivo dos dedos cerrados cria entre notas graves e agudas, acredito que essa diferença de dinâmica é inevitável, e que nem sempre isso deva ser considerado um problema. (FERRAZ, 2021) 
Outro gesto hibridizado de Eclusas é o "tap de ponta de dedo seguido de glissando", cujas velocidades Stanley Levi explora à vontade em sua versão. Enfim, o "glissando percutido de finger-tap" é uma técnica híbrida semelhante à anterior pois também combina os mesmos dois gestos (tap e glissando), mas de forma diferente. Enquanto a primeira realiza um tap apenas sucedido de um glissando continuo, o segundo, que encontra um antecedente na icônica obra brasileira para violão do século XX, Ritmata de Edino Krieger, faz com que o glissando seja percussivo em toda a sua extensão.

O final de Eclusas (p. 3) e o meio e fim de Ladainha (p. 2 e p. 4) ainda aplicam a ideia em uma certa serialização das nuances, promovendo a sucessão em cadeia de $f$ e $p$ extremos a cada 2-3 notas.

Interessante é ainda observar que de alguma forma há uma sintonia entre as ideias sobre técnica estendida e serialização de técnicas instrumentais, aqui empregada, e as pesquisas musicais e científicas conduzidas pelos dois violonistas para quem Ladainha e Eclusas são dedicadas. Por exemplo, rapidamente se vê que a parametrização de gestos tem uma afinidade direta com uma hipótese maior que Daniel Murray lança em sua dissertação de mestrado, segundo a qual "técnicas estendidas ou expandidas podem surgir de mescla, junção, integração ou hibridização de dois ou mais elementos da técnica tradicional ou de maneiras de tocar" (VASCONCELLOS, 2013, p. 20).

\footnotetext{
$\mathrm{Na}$ época da Ladainha, a gente não falava nisso, mas mais tarde sim; no meu mestrado, íamos de massa critica pra Unicamp, conversando sobre essas coisas. Sempre tive muita afinidade com as ideias do Silvio. Na Ladainha não tem tanto essa ideia da hibridização... Nessa época a expressão "técnicas estendidas" não existia para mim. A área de performance não era tão desenvolvida $[\ldots]$ É como se você fosse aproximando duas coisas, de repente você aproxima tanto que você sobrepõe: dependendo do que você fizer, ou quantas vezes você precisar fazer um gesto, ou da velocidade com que você precisar fazer um gesto, você cria um novo jeito, uma nova técnica (VASCONCELLOS, 2021).
}

Stanley Levi, por outro lado, calcou grande parte de suas pesquisas, em mestrado e em doutorado, no estudo da técnica do violão, na compreensão do que chamou de seus três grupos técnicos (ponteado, rasgueado, percussivo), e na realização de um "trabalho de levantamento, análise, descrição, catalogação e sistematização de recursos percussivos" (HANAN: FERNANDES, 2017, p. 57). Ao classificar todo um repertório 
de gestos percussivos, estabeleceu três parâmetros e nomenclaturas: a região do instrumento, a técnica empregada pelo instrumentista para acioná-la - que chamou de recurso instrumental, e o resultado sonoro ou "efeito acústico da interação região-técnica" (HANAN, LEVI FERNANDES, 2017, p. 56-57). Classificando em seguida os sons percussivos que se obtêm segundo as partes e sub-partes do violão, e as partes e subpartes das mãos, trouxe uma importante contribuição à compreensão e à utilização serializada dos recursos percussivos no violão (LEVI FERNANDES. In: LEVI FERNANDES et al., 2021).

\title{
No violão
}

Dissemos que Ladainha e Eclusas empregam uma escordatura microtonal em duas cordas soltas do violão. Frequentemente, esse tipo de sonoridade é buscado através de procedimentos mecânicos como vibratos, glissandos e bend, técnica esta que é emprestada da guitarra elétrica.

\begin{abstract}
A sonoridade imaginada na composição tanto de Ladainha quanto de Eclusas tem os microtons permanentemente presentes, alterando a própria estrutura de ressonância do instrumento. Não cabendo, assim, estratégias de bend. Distingue-se assim um pensamento linear, melódico, que tem nas notas como partes de uma linha de sucessão, daquela de um pensamento transversal harmônico e da composição de estruturas específicas de ressonância, com cordas ressoando juntas e muitas vezes deixando que o batimento entre elas se faça presente.

De certo modo, essa estratégia retoma aquela empregada por Gérard Grisey na escordatura do piano em Vortex Temporum. Para a realização da peça, Grisey indica afinar um quarto de tom abaixo as notas Dó2 e Lá3, e um quarto de tom acima as notas Ré3 e Fá4. Assim, quanto tocadas junto com as outras notas em afinação regular, é o sistema todo do piano que muda de timbre, realçando estruturas de batimento como temos na sonoridade de espectros inarmônicos, tais os dos gongos tailandeses. (FERRAZ, 2021)
\end{abstract}

De fato, em uma escordatura tão próxima às notas habituais e ao menos para se estudar, frequentemente os instrumentistas se contentam em dedilhar suas cordas na altura habitual, simplesmente para se poupar o esforço de mudar a escordatura, pois "muita coisa já era possível de se fazer assim, e eu fui testando" (MURRAY VASCONCELLOS, 2021). É importante realçarmos que, ao elevar a quarta corda e abaixar a terceira, grande parte das digitações e posições de acordes já são 
predeterminadas: todas as notas tocadas nessas cordas estarão alteradas, respectivamente, $1 / 4$ de tom acima ou abaixo da afinação usual.

Essa escordatura é bem interessante porque ela fica bem no meio do violão e tem coisas, dependendo da digitação que você faz, que soam absolutamente afinadas, e outras, completamente desafinadas. Naqueles acordes, principalmente naqueles Sis, tem sempre alguma coisa no meio, que fica mais escondido, que choca... (MURRAY VASCONCELLOS, 2021).

Porém, o incômodo idiomático que a escordatura escolhida nas duas obras acarreta provém de um fator mais profundo, que é o fato de ela desestabilizar e questionar o universo sonoro do violonista em dois quesitos, revelando ao mesmo tempo dois "pontos fracos" do próprio instrumento: a instabilidade da afinação e a diferença de tensão entre as cordas que são e que não são revestidas em metal:

\begin{abstract}
Para mim foi complicado aceitar uma escordatura microtonal, a primeira vez em que eu toquei [Ladainha]. "O que é isso, tudo desafinado?!". Demorei para entender como soa o violão nessa afinação. Entender que eu precisava mostrar isso, e não esconder. É como se botássemos a mão na ferida: o violão já é desafinado, assim ficou mais ainda... mas aí tem uns negócios nordestinos super interessantes: esse Si-Si-Si [o tricorde em falso uníssono] começa a virar algo meio mixolídio e depois tem uns acordes... eu comecei a entender a peça por uma razão que tem a ver também com a minha família, minhas tias nordestinas de idade, as igrejas, e um jeito de falar, em que acaba aparecendo um certo sotaque nordestino... de que hoje eu tenho mais consciência para explorar.

Outro problema é que a quarta corda [Ré] já é mais tensa, e com a escordatura, fica mais tensa ainda; o Sol [terceira corda] é mais mole, tem uma sonoridade mais fechada, e a escordatura só acentua isso. Para completar, a segunda corda grita... então, como lidar fisicamente com as cordas, com as dificuldades de tensão que essa escordatura traz para a mão direita (e na esquerda também, com as aberturas que você tem que segurar)? Como aproveitar da exacerbação de uma coisa que normalmente o violonista quer esconder, compensando a passagem da 4 a para a 3 a cordas (e não aumentando-a ainda mais)? Parece que a obra vai justamente na ferida, gerando um desafio técnico... Além de mexer com a ressonância simpática do violão, ela mexe com a técnica do violonista. Em realidade, precisa ter muita técnica para fazer aquilo soar bem, na velocidade... (MURRAY VASCONCELLOS, 2021).
\end{abstract}

Vê-se que, de alguma forma, o embate que a escordatura de Ladainha trouxe a seu violonista, e que consiste justamente em um questionamento fundamental que a obra traz, é o embate entre a materialidade do próprio instrumento e a do nosso corpo, ao 
desmontarem-se os lugares comuns da sonoridade, da constituição física e do gesto instrumental do violão.

Ainda no sentido de desmontar o lugar comum do instrumento, sua sonoridade e estabilidade, um outro aspecto importante de Ladainha e Eclusas é a forte presença de recursos percussivos ao violão, caracterizando as sonoridades secas que, como mencionado acima, se contrapõem às ressonantes. Eles compõem dois tipos de texturas descritas por Stanley Levi: integrando um tecido complexo des-hierarquizado em meio a sons de alturas definidas ou em aparições pontilhistas (LEVI FERNANDES, 2017, p. 25).

Por um lado a bula de Ladainha não especifica técnicas precisas de percussão no violão, apenas solicitando que se tente "produzir sons diferentes - sons mais ou menos agudos", deixando de resto uma margem de liberdade à contribuição do performer. Nesta obra, no entanto, o contraste seco-ressonante é mais presente, inclusive pelo fato dos gestos percussivos, à exceção do pizzicato Bartók, serem todos feitos na madeira. Em Eclusas, por outro lado, encontram-se gestos percussivos em maior número, além de mais especificados. Dentre estes, aqueles que são na madeira correspondem, na bula, aos itens 2 e 4 . Os demais recursos percussivos (itens 1, 5, 7, 8 e 9) são gestos que envolvem uma ou mais cordas (Figura 11).

Embora se assemelhem a certas percussões na madeira que já têm um forte histórico no repertório violonístico (tambora seca e Golpé, sobretudo), os dois recursos percussivos em madeira de Eclusas se diferenciam desses outros sobretudo no plano gestual pois, como discutiremos abaixo, cada um evoca uma imagem. Ademais, eles não correspondem àqueles no tocante à região do violão em que se percute e aos dedos e partes dos dedos empregados para percutir (a tambora seca se faz sobre o cavalete, e o Golpé, técnica emprestada do violão flamenco, abaixo do cavalete com o anular direito).

As Figuras 11 e 12 contêm o recurso descrito como "percussão com polegar e anular pronossupinados nas imediações das seis cordas" (segundo item da bula, Figura 8). Tratase de um tipo de tremolo percussivo, realizado diretamente no tampo, um acima (com o polegar) e o outra abaixo (com o anular) das cordas. O impacto sobre as cordas se dá com a borda dos dedos. "A imagem que proponho é a de um tremolo de uma oitava no piano: polegar e anular tocam no corpo do instrumento com as cordas sob eles" (FERRAZ, 2021). 
Figura 11 - Silvio Ferraz, Eclusas, bula completa.

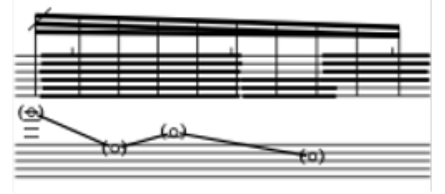

Percutir com pontas dos dedos cerrados da mão direita sobre as cordas indicadas, a mão esquerda deve fazer glissando de pestana tendo a nota indicada como relativa à $6 \mathrm{a}$. corda.

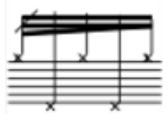

percussão com polegar e anular (pronossupinados), nas imediações das 6 cordas, direto sobre o corpo do instrumento.

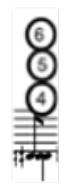

tricorde empregando as 3 cordas indicadas, deixar soar

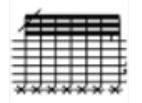

percussão com ponta dos dedos (4 dedos cerrados) na parte inferior do tampo do instrumento.

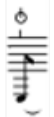

slap : bartok pizz.

Fonte: Ferraz, 2019, p. x.

Figura 12 - Silvio Ferraz, Eclusas: trinado de falsos uníssonos seguido de gestos percussivos 2 e 1, na ordem da bula.

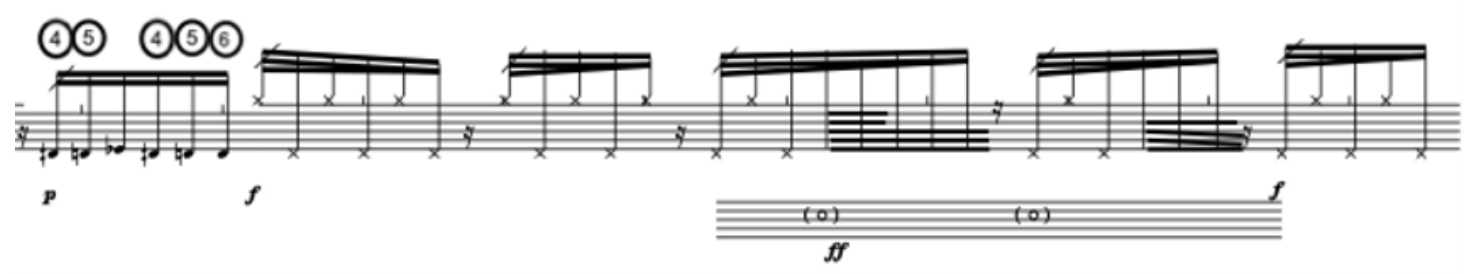

Fonte: Ferraz, 2019, p. 1.

O tremolo percussivo de Eclusas dialoga com outro gesto da obra que, embora empregue sons de alturas definidas, também resulta em um gesto textural: o trinado de 
sétima (Figura 15, mais abaixo). Ademais, ele se assemelha a um recurso percussivo presente nas obras do século XX para violão de William Albright e Reginald Smith Brindle, que teriam inventado uma forma de rolar de tambor, a tambora tremolando (LUNN, 2010, p. 38). Esses recursos seriam herdeiros, de alguma forma, do trinado de duas notas, um gesto caracteristicamente barroco.

Por sua vez, o quarto item da bula ("percussão com ponta de quatro dedos cerrados na parte inferior do tampo") propõe uma posição dos dedos da mão direita tal, que são as unhas dos dedos polegar, indicador, médio e anular que primeiro percutem sobre o tampo inferior, uma região sensível em termos de luteria instrumental. Segundo Stanley Levi, essa percussão deve ser devidamente adaptada afim de não provocar fissuras (LEVI FERNANDES. In: LEVI FERNANDES et al., 2021). Observe-se que um ataque similar de unha sobre o tampo abaixo do cavalete faz parte do mencionado Golpé (LUNN, 2010, P. 38), à diferença de empregar apenas o dedo anular, e deste estar em um ângulo não estritamente perpendicular ao tampo, como no caso de Eclusas (Figura 13).

\footnotetext{
Eu acho que quando o Silvio bolou isso, não lembrou que violonista tem unha grande. Pra você tocar perpendicular [sic], você não pode ter unha, por duas razões: se você toca assim, a unha não atinge bem, ela desliza, e depois sua unha vai durar trinta minutos... No tampo do violão, dependendo da região, não é aconselhável percutir com a unha, a não ser que se faça com uma certa moderação e não na região grave ao redor da ponte, onde o violão é mais sonoro. (LEVI FERNANDES. In: LEVI FERNANDES et al., 2021)
}

Figura 13 - Silvio Ferraz, Eclusas: percussão com as pontas dos dedos.

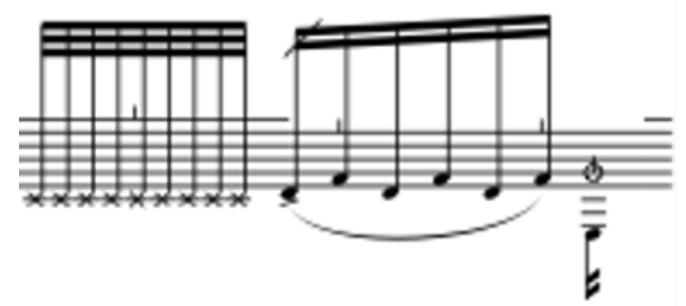

Fonte: Ferraz, 2019, p. 2. 
Stanley Levi não entendera, em realidade, que o movimento dos dedos cerrados deveria adotar uma direção perpendicular com relação ao tampo, e por isso realizou uma percussão com os dedos "colados" uns aos outros em suas extensões (essa foi a maneira como entendeu o termo cerrado), mas percutindo com a mão espalmada, não com unhas, em maioria ao lado cavalete, e mais raramente abaixo da roseta.

\begin{abstract}
Não é que a percussão no tampo tenha que ser forte, pois a importância está no bater de dedos fora das cordas, mantendo o fluxo dos trilos e trêmulos realizados sobre as cordas. Isso deve remeter mais a um imaginário do cochicho, da fofoca entre vizinhas ligada à sonoridade mais intimista do violão, do que ao som forte percutido. Em Eclusas, ao contrário de Ladainha, eu localizei um pouco mais as percussões perto das cordas. Porém, com Stanley não trabalhei diretamente, apenas ele me enviou mensagens perguntando como fazer, e dei umas dicas dentro de minhas restrições. O que te mostrei é o que desejaria que fosse feito, mas pode ser que soe pouco... Mantendo sempre o mais importante - o fluxo de impulsos, tendências -, sei que a peça vai funcionar. (FERRAZ, 2021)
\end{abstract}

Como vimos acima, o movimento (de quatro dedos cerrados e estendidos atingindo o tampo com unhas) constitui um gesto que também acontece sobre as cordas, combinado a glissandos de pestanas (Figura 6). Assemelhando-se longinquamente a um recurso percussivo existente desde o século XIX - a tambora sonora -, a percussão sobre cordas de Eclusas constitui um recurso original, que não tem precedente no repertório, embora não convenha falar em inovação técnica (LEVI FERNANDES. In: LEVI FERNANDES et al., 2021). Ao contrário da tambora sonora, ela é feita em uma região intermediária entre a escala e o cavalete; ela não busca um som grave imitando o do tímpano orquestral; ela implica a ação de mais do que um dedo da mão direita sobre as cordas, esta ação usando os dedos em suas pontas (e não estendidos). Por essas características, esse recurso provoca leves sons transientes resultantes do choque entre as cordas e os trastes no final do espelho e das notas que compõem os chamados bi-tons, que soam dos dois lados da corda a partir do contato do dedo no golpe percussivo. Não chegam, todavia, a caracterizar os bi-tons tal como aparecem no repertório violonístico do século $\mathrm{XX}$ (LUNN, 2010, p. 31).

A forma gestual dos dois recursos percussivos de dedos cerrados evocaria, como dito, a imagem de uma "fofoca". A evocação é visualmente muito eficiente; porém, o intérprete aponta duas concessões que elas implicam no resultado sonoro, que se 
acentuam quando se faz essa técnica sobre as cordas: uma com relação ao volume sonoro, e outra com relação ao número de cordas que se consegue atingir.

\begin{abstract}
Eu nunca tinha entendido que era pra fazer dessa forma, pois existem duas perpendicularidades possíveis com relação às cordas do violão. Se eu tivesse feito na ponta dos dedos, apareceriam no som outras características, que não são necessariamente um problema: ao atingir menos cordas, a percussão resultaria em um menor volume, com um nível dinâmico muito baixo. Além disso, a técnica é difícil de fazer. Mas o verdadeiro problema é que a partitura pede para atingir 6 cordas, coisa que é impossível para quem tem mão pequena. Eu até consigo inclinando um pouco a mão, pegando em um ângulo que desvia da unha... Eu teria que perguntar para ele [o compositor] o que ele espera do resultado sonoro, porque quando você bate e tira a mão, a mão traz a corda um pouquinho de volta e dá uma vibradinha que traz uma sutil ressonância das frequências que você está modulando com a mão esquerda quando se está tocando muito pianinho... Se você começa a tocar muito forte, isso vira um recurso percussivo que a gente chama de slap ou chasquido, a sonoridade da corda batendo no último traste. É possível tirar esse mesmo som se você tocar uma tambora bem pianinho, mas o problema é que a peça já começa em fortissimo, e muito rápido. Eu não sei até que ponto isso iria funcionar..
\end{abstract}

Ao mesmo tempo, se o importante é o gesto, e que ele [o compositor] topa desistir do $f f$, então tudo bem. Depende do que se quer: o som da corda batendo nos trastes ou um pouco mais das frequências. Eu achei que fossem as frequências, pois o mais difícil dessa técnica é o deslizamento da pestana. Não teria sentido fazer isso se o resultado sonoro fosse um som inarmônico. (LEVI FERNANDES. In: LEVI FERNANDES et al., 2021)

Vê-se na estreia de Eclusas, durante a V Bienal de Musica Brasileira Contemporânea do Mato Grosso, em outubro de 2018, que, devido à dificuldade de realização de pestanas para além da décima casa, Stanley Levi optara por substituir algumas dessas pestanas por posições em que quatro dedos apoiam sobre quatro cordas, e outras, por uma técnica de harmônicos.

A bula de Eclusas apresenta quatro recursos percussivos cujas nomenclaturas derivadas do inglês denotam uma abertura estilística voluntária, se aproximando da técnica do tapping, herdeira da guitarra elétrica, e do Fingerstyle moderno ${ }^{10}$ : slap, scrap,

\footnotetext{
${ }^{10}$ Embora já existam no repertório tradicional do instrumento - por exemplo, em práticas populares como o flamenco, o folclore argentino e a música urbana (LEVI FERNANDES, 2017, p. 25) - pode-se dizer que as técnicas percussivas têm promovido uma verdadeira ampliação das competências do violonista do século XXI, graças ao desenvolvimento do violão fingerstyle moderno, gênero de nomenclatura anglo-saxã que tomou forma a partir de 2006, além da música clássica contemporânea (LEVI FERNANDES; BRAGA; CARPENEDO, 2021).
} 
tap seguido de glissando e glissando percutido de finger-tap ${ }^{11}$ (Figura 11). Destes, os dois últimos utilizam a técnica do tap em uma versão reinterpretada. À leitura da partitura, os taps de Eclusas consistem, no geral, mais precisamente de martellatos que de tappings, pois, para percutirem de forma precisa uma nota da escala, eles se servem exclusivamente dos dedos da mão esquerda ${ }^{12}$. Também chamado técnica de bi-tones, esse "ligado ascendente de sonoridade percussiva" permite a audição de um "som duplo e simultâneo" (INDA, 1984, p. 17), sendo a nota digitada a mais audível, e sua camada destemperada (o "lado esquerdo da corda"), a menos (VASCONCELLOS, 2013, p. 120).

Embora na gravação de Stanley Levi nem todos os taps seguidos de glissando soem percussivos, o violonista parece valorizar os glissandos, propondo diferentes velocidades a cada um. Por outro lado, em todos os "glissandos percutidos de finger-tap", Levi optou por utilizar a técnica do tapping de Fingerstyle, que alterna rapidamente um dedo de cada mão na constituição de uma textura de taps. Portanto, nestes, a percussão dos dedos sobre as notas é bastante audível. A Figura14 abaixo encadeia "taps de ponta de dedo seguidos de glissando" e scraps, que se realizam "raspando a corda longitudinalmente com unha, com ataque percussivo". Essa técnica, que aparecera no repertório do violão erudito primeiramente em La Espiral de Leo Brouwer enquanto "glissando com unha", tem na interpretação de Stanley Levi o efeito sonoro potencializado pela adição de uma espécie de vibração de mão esquerda, que permite o prolongamento do ruído consequente. De fato, alguns scraps de Eclusas possuem uma linha frisada prolongando seus sons (o Mi bemol, o Fá sustenido e os dois Dos sustenidos), e outros não (Ré, Mi, Lá bemol, etc..., no final da linha).

\footnotetext{
${ }^{11}$ Stanley Levi realizou, em seu doutoramento, um estudo aprofundado dos recursos percussivos no violão. Dentre os recursos catalogados e ordenados segundo sua maior ou menor frequência de utilização no repertório, podemos identificar cinco relacionados aos empregados em Eclusas, dentre os quais o "golpe sobre as cordas" seria o de maior incidência em sua catalogação, seguido do "golpe no tampo com os dedos indicador-médio-anular juntos ou alternados", do "tapping percussivo", do "pizzicato Bartók" e da "raspagem de unha nas cordas" (HANAN; LEVI FERNANDES, 2017, p. 60).

${ }^{12}$ Ao passo que os ligados ascendentes percutidos do martellato costumam ser feitos, desde sua aparição ainda no século XIX, por dedos da mão esquerda (ROMÃO, 2012, p. 1299), a tapping technique é comumente mais relacionada à mão direita, mas também se estende à esquerda, quando tocada em alternância com aquela, na chamada touch guitar (TAPPING, s.d.).
} 
Figura 14 - Silvio Ferraz, Eclusas, linha 2: taps seguidos de glissando, pizzicato Bartók, scrap e scrap prolongado.

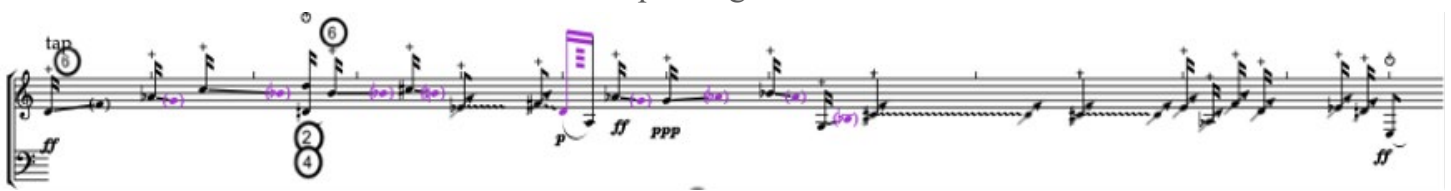

Fonte: Ferraz, 2019, p. 3.

Stanley Levi se concentrou em "entreter" o som do raspar da unha no scrap, variando de acordo com o comprimento da linha frisada a duração desse som, mas não se ateve a realizar o "ataque percussivo" que a partitura indica. Ele comenta:

\begin{abstract}
Ainda não tenho certeza do que ele quer. Parece que ele gostaria de uma coisa que seria o inverso do que o Leo Brouwer faz no La Espiral Eterna: "schhhpam" (mão direita - glissando de unha, depois esquerda martellato). Acho que ele quer o contrário, ele quer "pamschhhhh”. Depois que você trouxe o problema, estou achando que é isso, eu não tenho certeza. Essa interpretação teria problemas, porque a nota some, dependendo da pressão que você coloca... O violão é muito manhoso, qualquer coisinha que você muda, ele gera um resultado diferente, principalmente nas cordas graves. Se você bate e faz um deslizamento com uma pressão muito suave, a corda continua vibrando e gera um efeito que a gente chama de tsinga, que é quando você vibra a corda e encosta a unha, fazendo "dzzzz". O problema é que o som do deslizamento fica mais sutil. Se você coloca um pouco mais de pressão você escuta melhor o som do deslizamento, só que a nota some. Então são coisas diferentes que você executa praticamente do mesmo jeito, só variando a pressão. É como a diferença entre um estalo e uma tambora: se você a toca forte demais, ela vira um estalo. O violão tem essas manhas, que não são tão simples assim. Eu fiz daquele jeito porque a notação dele me induziu a pensar que tinha um prolongamento da nota. Se fosse hoje eu não resolveria daquela forma; mas foi bom que eu acabei inventando aquele negócio [seu dedo 1 da mão esquerda se arca e vibra, como ao fazer cócegas]... Isso não existia e foi ótimo tê-lo inventado, porque permite prolongar a nota. Mas faltou o ataque e isso de fato não foi bem resolvido da minha parte. (LEVI FERNANDES. In: LEVI FERNANDES et al., 2021)
\end{abstract}

Eclusas, como Ladainha, ainda se vale abundantemente de um recurso percussivo amplamente explorado no repertório do violão do século XX, tendo sido introduzido neste a partir de La Espiral Eterna de Leo Brouwer em 1971 (VASCONCELLOS, 2013, p. 21), o pizzicato Bartók. O efeito é nomeado slap na bula de Eclusas, e se produz com o puxar enérgico de uma corda, provocando um ruído de ataque e ricochetear da corda contra o espelho. 
Ademais, Ladainha explora o próprio grupo técnico ponteado enquanto recurso semi-percussivo, ao opor, em um tecido sonoro complexo, acordes secos (sem deixar vibrar), geralmente tocados em $f$ e plaqués a arpejos ressonantes (campanellas-clusters), tocados em $p$ (Figura 2).

Como discutimos acima, a estrutura de ambas as obras é calcada na alternância contrastante entre essas variadas sonoridades secas e elementos ressonantes, estes sendo herdeiros de técnicas de ponteado (arpejos e tremolos, que se agrupam, grosso modo, em uma categoria textural). Esse funcionamento do material musical - a que se vale inclusive de certos idiomatismos do instrumento, como a exploração acústica da ressonância de cordas soltas, fator amplificador do som (MACIEL, 2010, p. 30), mas também da inserção do ruído, sob a forma de recursos percussivos - se insere em uma tradição latinoamericana de composição contemporânea para violão, que teria em Edino Krieger, Leo Brouwer e, ainda antes, Heitor Villa-Lobos seus antecessores icônicos.

Observe-se nesse sentido que há, na exploração das diferentes texturas do ponteado em Ladainha e Eclusas, uma certa tendência a amalgamá-las indistintamente. Arpejos se transformam em trinados, tremolos, combinando livremente e alternando falsos uníssonos sobre várias cordas, efeito que não pode deixar de lembrar o tremolo em três cordas do Estudo 7 de Villa-Lobos (LUNN, 2010, p. 74). Ao realizar essas passagens texturais, e radicalizando o procedimento de combinação livre de técnicas de mão direita, Levi buscou soluções tipicamente violonísticas, optando por mesclar aos tremolos algumas hibridizações não previstas na obra, como o glissando de um dedo da mão direita por todas as cordas. Precisamente esta técnica, que se situaria entre o strumming emprestado ao violão folk e popular (WEISS, 2019, p. 238) e o rasgueado, associado ao violão flamenco e sul-americano (LEVI FERNANDES. In: LEVI FERNANDES et al., 2021), é empregada por Levi na realização dos rápidos e longos arpejos que a última linha da partitura pede.

Interessante notar é que, como desenvolvimento do tremolo-trinado sobre intervalos de uníssonos desafinados que vão progressivamente se ampliando (segundas, terças...), Eclusas extrapola o âmbito dos pequenos intervalos e desenvolve a ideia de um certo trinado expandido. Este possui uma semelhança gráfico-visual e sonoro-gestual com o recurso percussivo pronossupinado (item 2 da bula), em que a alternância rápida 
dos golpes do polegar no tampo superior e do anular no tampo inferior funciona também como um trinado (Figura 15).

Figura 15 - Silvio Ferraz, Eclusas, linha 5: tremolos percussivos e trinados de sétima.

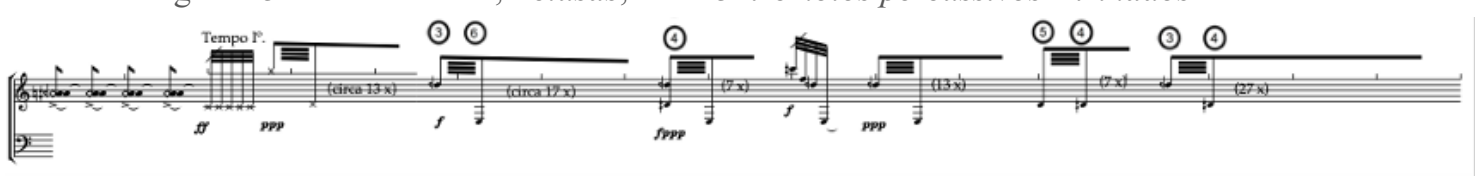

Fonte: Ferraz, 2019, p. 2.

Ao se apropriar dos recursos e características do violão e da escrita para violão, de suas possibilidades técnicas (físicas, mecânicas) e expressivas (por exemplo, as texturas em ponteado, a qualidade seca de acordes plaqués e de recursos percussivos consagrados), Ladainha e Eclusas estabelecem um diálogo entre dois tipos de idiomatismo: o instrumental, e o idiomatismo da escrita particular dessas duas peças, este englobando seus processos composicionais, suas formas de expressão e de estilo (KREUTZ, 2014, p. 103-104).

\begin{abstract}
A peça do Silvio tem bastante identidade e uma sonoridade própria, que tem a ver menos com o material sonoro empregado (isto é, ela não é, no fim das contas, tão "barulhenta"), e mais com a forma como os elementos estão combinados, por mais comuns que sejam (LEVI FERNANDES. In: LEVI FERNANDES et al., 2021).
\end{abstract}

Assim o próprio questionar dos gestos comuns do violão - e a forma dialética como esse questionamento é feito - constitui em termos de estilo compositivo uma "estética muito pessoal, $[\ldots$ ainda que...] as coisas que ele vai inventando vão entrando pro repertório de técnicas do instrumento" (MURRAY VASCONCELLOS, 2021). Colocando-se a meio caminho entre um mergulho nos recursos considerados violonísticos e sua negação, as duas obras atestam de uma certa recusa do recurso idiomático do instrumento por si, mas não propriamente de seu abandono.

Por um lado, meu pensamento composicional procura investigar as potencialidades do gesto, ao invés de buscar recursos característicos do 
violão. Os movimentos que Arthur Kampela chama de ergonômicos são na realidade gestos próximos. Ao contrário, eu penso como Ferneyhough em sua obra para violão Kurze Schatten II, em explorar justamente os gestos não-ergonômicos, que criam gestualmente outras coisas, promovendo uma verdadeira dança, pelo fato de os gestos não serem próximos.

Em Eclusas, por exemplo, existe uma espécie de migração do gestual pianístico para o violão. Nesse sentido, deveríamos poder ver e ouvir cada uma das notas dos harpejos, ou seja, elas teriam que ser dedilhadas individualmente, ao invés de serem tocadas juntas em gestos de deslizar de um dedo por todas as cordas. Um harpejo dedilhado permitiria assim que se ouvissem todos os intervalos entre as notas.

Este é o outro aspecto de minha música: tenciono pensar o intervalo, de maneira vocal. Como diz o Roberto Victorio, as notas bem poderiam ter sido outras, mas o que é mais importante é o intervalo, o batimento. Em realidade, na escrita das duas peças, tem muito conteúdo de improvisação. Assim, o trabalho conjunto com Daniel Murray foi o de buscar o afeto temporal e sonoro da música, mais do que as notas. (FERRAZ, 2021)

No entanto, a noção de idiomatismo instrumental resvala também a de exequibilidade que, nos exemplos de Ladainha e de Eclusas, suscitou reconsiderações e desencadeou revisões dos primeiros manuscritos - sobretudo com relação aos acordes e às extensões de dedos da mão esquerda (KREUTZ, 2014, p. 117). Assim, graças a uma leitura ao violão em parceria com o intérprete, acordes de impossível execução em Ladainha foram modificados: tal é o caso do último acorde da Figura 1, cuja nota mais aguda não pode ser feita na primeira corda por ser meio tom abaixo da corda solta e, tendo em vista as notas alteradas de um quarto de tom, torna-se impraticável sem retirar definitivamente o Do sustenido do acorde.

\begin{abstract}
Dei uma mudada de leve nos acordes. Tudo é possível, mas tem acordes muito difíceis. O Silvio tinha uns chartes no canto do manuscrito da partitura que esquematizavam como "escrever para cordas", indicando possibilidades de acordes que considerassem as seis cordas e quatro trastes. Mesmo assim, havia acordes muito próximos uns dos outros, e as mudanças tinham que ser rápidas, de forma que ficava muito difícil de encadear... Mas foi interessante entender que essa dificuldade dos acordes tinha a ver com a expressividade da peça. (MURRAY VASCONCELLOS, 2021)
\end{abstract}

Eclusas também necessitou de uma modificação em certas passagens com grandes extensões de mão esquerda por ocasião de uma revisão que nós, autores do presente artigo, tivemos em outubro de 2018. 
As razões que levaram um ou outro intérprete a escolher digitações e gestos violonísticos diferentes dos imaginados pelo compositor (por exemplo, o acima mencionado gesto de deslizar o dedo anular em um gesto perpendicular às cordas, da primeira à sexta, que evoca técnicas emprestadas do violão flamenco), são musicalmente fundamentadas, e caracterizam uma maneira de pensar a interpretação musical. Com efeito, rasgueados e gestos glissandos desse tipo "não necessariamente eliminam a individualidade das notas [mas] soam mais legato que o harpejo, lá onde a partitura apresenta ligaduras" (STANLEY LEVI, 2021). Ambas as visões (a de um fraseado legato, e a concepção de um gesto sonoro e físico) constituem argumentos muito consistentes embora antagônicos, em uma busca (que, ela sim, é comum) pela expressão musical.

O questionamento que proponho ao compor para o violão é, por um lado, o do "como procurar uma musicalidade que escape aos clichês do instrumento, aqueles recursos que sempre 'funcionam' bem" - no caso do violão, os bends, rasgueados, rubatos e uma maneira muito típica de fazer chorar o instrumento. Assim, o ponto de partida de Ladainha e de Eclusas não é o violão; é a voz humana, é uma fala, é a percussão que está numa fala, o batimento que está numa fala que chora. Este é o porquê da escordatura, que considero imprescindível. (FERRAZ, 2021)

Ao nos defrontarmos com partituras escritas depois de 1969, depois da estreia de Pression de Lachenmann, é importante sempre ter em vista o universo sonoro do compositor, suas referências, e abrir-se para além da leitura já constituída pelo repertório. Pois para cada compositor distinguem-se as fontes de onde nasceram suas técnicas e sonoridades, advindo da percussão, da eletroacústica, da música vocálica, dos gestos instrumentais, de gestos cênicos, de sons ambientais etc. ${ }^{13}$

\begin{abstract}
A leitura de uma partitura direto, a partir de hábitos de repertório, muitas vezes pode levar a caminhos muito distintos daquele que o compositor indica e quase sempre trazendo uma aparente dificuldade, que não era presente na concepção da peça. Erro do compositor em não especificar tudo, erro do sistema de notação que é limitado? (FERRAZ, 2021)
\end{abstract}

\footnotetext{
13 Ainda nesse sentido teríamos as estratégias de escrita relacionadas à síntese instrumental como em Lachenmann, na sua música concreta instrumental, ou ainda em Berio, sintetizando um tambor com a concomitância de ataque percussivo e glissando com os dedos da mão esquerda batendo sobre as cordas mais o tamborilar de dedos da mão direita no tampo do violoncelo em sua Sequenza XIV (cf. TEIXEIRA DA SILVA; FERRAZ, 2015b; KAFEJIAN; FERRAZ, 2017).
} 


\title{
Diálogos com a performance
}

As situações em que as duas obras foram compostas, somadas à relação que pôde se estabelecer com Daniel Murray e com Stanley Levi, foram diametralmente opostas. Ladainha foi praticamente uma encomenda do intérprete que, na época, era aluno da faculdade Santa Marcelina e tinha recebido um prêmio da Petrobras para gravar um $c d$. “Estávamos sempre juntos, e sempre conversávamos. O meu desafio era encorajar o Silvio a escrever para violão e gravar o primeiro disco" (MURRAY VASCONCELLOS, 2021).

Apesar do convívio próximo, o início da concepção de Ladainha e as primeiras investigações de seu material, não nasceram da própria colaboração. Não houve um primeiro contato, segundo o violonista, em que este mostrasse formalmente "as possibilidades do violão" antes de se iniciar o processo de escrita, mas esta, de alguma forma, se impregnou da maneira de tocar de Murray, que conta, "ele na verdade me conhecia de ver tocando nos concertos de alunos" (MURRAY VASCONCELLOS, 2021:

\begin{abstract}
Ele já me deu a peça escrita; o que eu dei pra ele foi a minha leitura do que ele escreveu. O primeiro contato tocando a peça já foi o caderninho de padaria, que é o caderninho de anotações que ele sempre leva. Eu tentei ler, "é isso?", de uma lida à primeira vista, "legal, é mais ou menos isso". Acho que ele escreveu mais alguma coisa, xerocou o caderninho dele, arrancou uns pedaços de música e me mandou aquele manuscrito. Eu fiquei tão acostumado com o manuscrito que quando ele fez uma edição eu não me adaptei. No manuscrito tem as minhas digitações, anotações e as coisas que eu mudei, até hoje eu uso esse manuscrito. [...] Nos alimentamos muito de questões como "o que você pretende com isso?", "como soa a leitura?". (MURRAY VASCONCELLOS, 2021)
\end{abstract}

A partir desse primeiro manuscrito, e das leituras que Murray fazia, na casa do compositor, das páginas do caderninho que iam se acrescentando aos poucos, uma colaboração nasceu. $\mathrm{O}$ intérprete sugeria pequenas alterações, majoritariamente relacionadas a encadeamentos mais ou menos exequíveis, e a peça se estruturou a partir desses encontros e de um relativo rigor formal:

Como ele não me entregou tudo de um vez só, mas me mandava uma folha de cada vez, e eu não sabia direito a ordem das coisas (que foi mudando)... eu acho que algumas leituras minhas talvez tenham suscitado alguma solução na página seguinte (“Ah, vou explorar mais isso...”), mas afora 
isso, o processo foi "ele escrevia e eu tocava". (MURRAY VASCONCELLOS, 2021)

Por outro lado, o processo de criação de Eclusas se caracterizou pela distância física entre compositor e performer, e pela pressa em se montar a obra, cuja estreia foi prevista com prazo curto, em meio a um fim de semestre atribulado para ambos.

\begin{abstract}
O que aconteceu foi que o Roberto Victorio me convidou para fazer o concerto na Bienal dele e foi tudo feito em condições sub-ótimas em termos de tempo. $\mathrm{Na}$ minha cabeça, a gente iria estabelecer um processo de cooperação no próprio fazimento da peça, mas o Silvio acabou escrevendo muito rápido, e quando eu ia mandar uns materiais, a peça já estava pronta. (LEVI FERNANDES. In: LEVI FERNANDES et al., 2021)
\end{abstract}

Durante o processo de leitura da obra, Levi declara ter tido, e ainda ter, várias dúvidas sobre sua realização. Perguntas foram feitas e respondidas às pressas por e-mail, cogitou-se mesmo marcar uma vídeo-chamada, que, "como o tempo estava muito premente, acabou não acontecendo" (LEVI FERNANDES. In: LEVI FERNANDES et al., 2021).

Todas as peripécias por que o processo passou fizeram com que a colaboração não tenha encontrado espaço antes do concerto, ainda que o violonista lamente, "eu tenho certeza que se a colaboração tivesse acontecido com mais conversa, como eu desejava e eu imagino que ele também, a coisa teria sido um pouco mais nivelada". Além disso, o processo deveria ter culminado, alguns meses após a estreia, na gravação da obra. Porém, por razões diversas, o projeto foi adiado. "Agora está na minha lista de coisas a fazer em breve, gravar essa peça. Espero até o fim do ano" (LEVI FERNANDES. In: LEVI FERNANDES et al., 2021).

Como vimos em detalhe nos capítulos anteriores, remanesce que, na falta de tempo para trocas, há na decifração da partitura de Eclusas pontos em que os gestos instrumentais que Stanley Levi realizou alteram parcialmente os propostos na partitura, outros em que estes necessitariam de todos os modos uma revisão por serem, violonisticamente falando, pouco coerentes, e outros ainda em que o afeto buscado diverge do pensamento compositivo inicial. Todos esses pontos resultam, na prática, em escolhas técnicas (digitação, realização) diversas. 
Muitas adaptações foram coisas dessa natureza, posso dizer que eu nao achei solução melhor; outras vêm do fato de eu ter pego a peça quando a data de concerto já era iminente... por isso, a maior parte dos questionamentos técnicos tem uma razão mais prosaica, que tem a ver mais com as condições logísticas do que com o fato de eu ter determinado que uma coisa deveria ser assim ou não. Eu também preferia ter mandado todas as minhas perguntas juntas para o Silvio, mas infelizmente isso não aconteceu porque a peça é difícil pra caramba, e o meu tempo foi passando. Foi uma questão puramente pragmática. O que eu considero é que teria sido necessário ter uma conversa com o Silvio (LEVI FERNANDES. In: LEVI FERNANDES et al., 2021).

Nesse sentido, o registro audio-visual da estreia (ECLUSAS, 2019) revela uma interpretação "melódica demais" da passagem fluido e cantabile (Figura 7), que como explicado acima, em princípio deveria gestualmente representar bariolages. Um outro exemplo consiste nos tricordes sobre a nota $\mathrm{La}$, que no primeiro manuscrito apareciam grafados erradamente (Figura 10) e que poderiam ter sido facilmente esclarecidos caso a colaboração tivesse permitido se constatar, além do problema da exequibilidade (extensão de mão esquerda), que uma das três cordas necessariamente deveria ser a terceira, abaixada de $1 / 4$ de tom.

Não resta dúvida que um dos principais fatores que determinam e complexificam a relação entre composição e performance é a transmissibilidade (das ideias que compõem a obra musical, e que devem ser realizadas pelo performer). Esse fator, no caso da música escrita, incorpora diversas problemáticas, como as formas de notação e a invenção de "bulas" explicando gestos instrumentais.

\footnotetext{
A partitura sozinha não diz nada; a partitura é um arremedo de notação. Ela não tem como funcionar quando se trabalha com gestos. Nas duas peças para violão, eu não consegui resolver a notação. Eu sei qual é o solfejo daquilo; mas não sei qual é a notação. (FERRAZ, 2021)
}

Como observa Kreutz (2014, p. 110), a literatura musical para violão possui duas formas antagônicas de notação: a técnica (como a tablatura) e a musical, sendo que a "primeira prioriza as informações a respeito de como tal obra deve ser executada no instrumento, [...] sendo a música uma consequência da execução" e a segunda procura indicar o que deve soar. A bula, na notação musical, costuma ser a solução que guia o performer na execução da obra. Observa-se sua presença na partitura de Eclusas, e sua 
ausência na de Ladainha: nesta, a bula foi substituída por uma forma de transmissão oral, pois compositor e intérprete montaram a peça progressivamente juntos.

\begin{abstract}
Quando eu li a peça, parecia muito difícil; o solfejo era difícil. É o compositor quem ouve o que escreve, por isso ele cantava para mim o que imaginava. Eu ia aprendendo quase de ouvido, através da voz do Silvio cantando como seria a música que ele escrevera: foi um privilégio (MURRAY VASCONCELLOS, 2021).
\end{abstract}

O compositor que é ao mesmo tempo instrumentista, como no caso de Arthur Kampela quando compõe para violão, tem em sua própria performance a bula de como se toca a peça, e serve de modelo a ser imitado. Sua figura representa aquilo que Levi Fernandes (In: LEVI FERNANDES; BRAGA; CARPENEDO, 2021) conceitua como uma Tocautoria, capaz inclusive de desenvolver, a exemplo dos emblemáticos 12 Estudos para violão solo de Heitor Villa-Lobos, as possibilidades idiomáticas e expressivas do instrumento (KREUTZ, 2014, p. 108). Um compositor que não é violonista, ao contrário, deve compor com o material que lhe vem às mãos: a tradição escrita para violão, as técnicas estendidas tal como são notadas...

Como no caso de Ladainha e Eclusas, o problema da notação, e os possíveis ajustes que ela contém (cujas remodelações fazem parte do processo de sua reescrita), pode ser sanado quando o intérprete faz a leitura da obra junto com o compositor (tal foi o processo de Ladainha, em trabalho de decifração conjunto com o violonista Daniel Murray), mas torna-se dialético, abrindo a possibilidade a variadas interpretações, quando a leitura é feita pelo performer sozinho (como foi o caso de Stanley Levi e a partitura de Eclusas). Um ponto deveras pragmático que pode ser trabalhado em colaborações entre compositor e intérprete, é a busca de soluções de exequibilidade para determinadas passagens da composição. Exemplares seriam os diálogos entre o violoncelista Rohan de Saram (1939) e Luciano Berio em uma busca conjunta de maneiras de se realizar a ideia (o gesto e a sonoridade) do compositor (TEIXEIRA DA SILVA; FERRAZ, 2015a). Também foi através desse tipo de abertura ao diálogo e ao trabalho de pesquisa em conjunto com Daniel Murray que Ladainha foi encontrando sua forma final.

Em Eclusas, que "parece ser menos aberta que Ladainha, tendo gestos especificados e uma interpretação imaginada mais determinada" (MURRAY 
VASCONCELLOS, 2021), a complexidade de leitura reside sobretudo na compreensão dos próprios gestos instrumentais. De fato, no que diz respeito ao registro escrito de recursos percussivos ao violão, o problema da transmissão e compreensão do gesto se deve em grande parte à "falta de sistemas de notação consolidados e terminologia padrão [...] e à profusão de recursos percussivos similares com resultados sonoros praticamente equivalentes, mas sempre descritos de forma diferente e com diferentes nomes" (HANAN; LEVI FERNANDES, 2017, p. 56). O violonista comenta a dificuldade de interpretação da bula com relação aos dois gestos percussivos de dedos cerrados:

\begin{abstract}
Para mim a notação em si não foi um problema, mas sim a bula... Conversando, tudo se acerta. Eu até reli a bula da peça de novo um desses dias...Realmente não é fácil entender o que ela pede se o compositor não estiver na tua frente, te explicando. Uma bula mais extensa eventualmente com fotos e recursos audiovisuais, poderia ajudar. Esse desnível, de uma pessoa pegando um papel e tendo que a partir do papel gerar um produto, evidentemente que pode criar uma defasagem entre a imagem inicial que o compositor propôs e a performance. No entanto, isso não necessariamente é um problema, pois ela suscita outras questões, como: qual é o papel do intérprete, sua opacidade? Qual é o papel das mediações? Qual é o nível de autonomia criativa que existe em cada elo da cadeia? Ainda que eu seja bastante liberal com relação a isso, nesse caso específico [de Eclusas], eu gostaria de ter conversado com o Silvio, e ainda vou. (LEVI FERNANDES. In: LEVI FERNANDES et al., 2021)
\end{abstract}

Ao expor seu projeto de futuro diálogo, Stanley Levi sugere que um processo de colaboração não se termina na estreia de uma obra; ao contrário, esta marca apenas uma etapa das experimentações que caracterizam a criação musical. No caso de Eclusas, a relação de troca ainda mal começou. Da mesma forma, vê-se que a estreia de Ladainha, depois de idas e vindas entre o intérprete e o compositor, produziu um resultado sonoro e gestual que dialoga com a ideia veiculada pela composição no papel, mas constitui uma versão possível dela, dentre tantas.

Se com Daniel Murray, mudamos muito as notas mas mantivemos o afeto da musica, ja com o Stanley as mudanças foram menos drásticas, mas precisaríamos trabalhar juntos os afetos e as sonoridades da obra, pois Eclusas é um grande lamento, um grande choro. Teria que ver como o intérprete vai resolver esse afeto... Nas minhas músicas eu gostaria muito que o instrumentista criasse uma peça a partir da minha peça, como se esta fosse uma guia de objetos. (FERRAZ, 2021) 
A noção de uma guia de objetos confere às duas obras consistência, conceito emprestado de Deleuze e Guattari em que o plano formal não se desenvolve ou organiza, mas se compõe de afetos intensivos que se manifestam nas "relações localizadas de velocidade entre elementos" (FERRAZ, 1998, p. 92). Essa concepção também transparece na percepção de Ladainha por seu intérprete, que vê nela "o uso do violão como objeto sonoro, sem regras ou preconceitos de como deve ser tocado. Como algo 'encontrado' com seu funcionamento a ser descoberto e explorado criativamente, sem amarras" (MURRAY VASCONCELLOS, 2021). Dentro desse pensamento musical fundamentalmente enraizado no gesto instrumental, e que ao invés de reproduzir lugares comuns do instrumento, permite a re-descoberta de suas possibilidades, Daniel Murray também exalta a possibilidade que teve de, enquanto instrumentista, poder colaborar com um compositor, comentando:

\begin{abstract}
A invenção de novos gestos instrumentais, objetos sonoros, abre a possibilidade do intérprete talvez desenvolver uma coisa diferente, o que talvez deixe compositor feliz; talvez a colaboração que ele espera do intérprete seja até essa, dizendo, "estou incompleto, me complete de alguma maneira”. E você tem que pegar aquilo e fazer um outro negócio... Quanto à experiência de trabalhar com o compositor, você não sabe o que vai ser o "geral"; o geral está na cabeça dele ou ainda, ele está tentando descobrir junto com você. É um lugar interessante, pois você vai aprendendo as coisas junto com o compositor. Compor é um processo de aprender a própria música. (MURRAY VASCONCELLOS, 2021)
\end{abstract}

Embora Eclusas não tenha conhecido um processo de colaboração tão utópico, onde ambas as partes estivessem em processo de aprendizado de uma música idealmente já existente, as contribuições que Stanley Levi trouxe na versão que montou para sua estreia a partir de um confronto de choque, estranhamento e apropriação da peça, trazem a visão expert do violonista (que tem sua profundidade enraizada em superficialidades tais que padrões de digitação, tipos de toque, tipos de ataque, grupos técnicos, recursos timbrísticos...), revelando um conhecimento do terreno, corporal, que é crucial em obras de concepção gestual. O violonista admite que, dentro das circunstâncias que envolveram a estreia da obra, tenha se dado a "inventar ali, a ser muito livre mesmo", mas propõe uma visão salutar para a relação de reciprocidade e cumplicidade entre mediadores do fazer artístico. 
O intérprete é um mediador que trabalha em cima de outro mediador, que é a partitura. Se eu faço uma composição, ela tem sua vida independente; a gente não entende completamente as consequências daquilo que a gente cria. $\mathrm{O}$ compositor não é esse ser infalível e onisciente. Por isso é importante a relação entre compositor e intérprete... Preciso conversar com ele - o Silvio-, testar junto, talvez seja justamente dessa tensão que vá surgir uma terceira via que acomode tudo isso.

Ao mesmo tempo, aquilo que eu toquei lá não deixa de ser um produto, e não deixa de ser um produto muito interessante. E aquele jeito lá é fruto de equívocos que têm a ver com as questões prosaicas da logística, com as insuficiências da notação, com a bula um pouco imprecisa, com as minhas idiossincrasias enquanto intérprete e leitor, com minha interpretação, com a concepção do Silvio, tudo isso junto gera um produto inesperado, mas não acidental, que também é legal (LEVI FERNANDES. In: LEVI FERNANDES et al., 2021).

De fato, independentemente de projetos, premeditações e utopias, as obras de arte são fruto de suas histórias, e têm vida própria. Mesmo que depois elas venham a ter outras histórias e outras versões. A versão de hoje, que traduz essa história, sela sua vida independente justamente em sua concretude.

\section{Epílogo}

A música de Ladainha e Eclusas, construindo-se de velocidades, gestos, afetos, que procuram entrelaçar sobretudo um pensamento textural e gestual, mas sorrindo distanciada - e simpaticamente ao pensamento figural - contém em seu código genético os diálogos que entreteve com instrumentistas de uma tradição tão velha quanto nova, que é a do violão. Nesses diálogos, um jovem estudante respeitoso ao máximo do texto que lhe foi entregue procurou enriquecer a fermentação de Ladainha com seu gesto de colaborador; um professor já mais maduro, se vê sem espaço para ouvir mais atentamente o que prega o compositor, e ousa questionar em Eclusas, sem muito caso, o princípio mesmo da negação da tradição sem, por isso, querer restabelecê-la. A escuta reinventada procura seu próprio idiomatismo, e se ampara na concretude do fazer musical. As duas obras, sutilmente, são uma homenagem aos gestos violonísticos de seus violonistas. 


\section{Referências}

FERRAZ, Silvio. Eclusas for solo guitar. São Paulo: [s.n.], 2019. 1 partitura.

FERRAZ, Silvio. Ladainha for solo guitar with live transforming, comissioned by Daniel Murray. São Paulo: [s.n.], 2008. 1 partitura.

FERRAZ, Silvio. Música e repetição: a diferença na composição contemporânea. São Paulo: EDUC, 1998.

FERRAZ, Silvio. Semiótica peirceana e música, mais uma aproximação. Opus, v. 4, n. 4, Rio de Janeiro, 1997.

FERRAZ, Silvio, ALDROVANDI, Leonardo. Loop-interpolation-random \& gesture: Déjà vu in computer-aided composition. Organised Sound, v. 5, n. 2, p. 81-84, 2000.

GIACCO, Grazia. Geste et voix, entre corps et souffle: pour une didactique de la création artistique. Recherche en éducation musicale, n. 33, p. 63-90, 2016. Disponível em: http://www.mus.ulaval.ca/reem/index.html1. Acesso em: 14 dez. 2020.

GODØY, Rolf Inge; LEMAN, Marc. Prefácio dos editores. In: GODØY, Rolf Inge; LEMAN, Marc. (Org.) Musical gestures: sound, movement, and meaning. New York, London: Routledge Taylor \& Francis Group, 2010.

HANAN, Kestern; LEVI FERNANDES, Stanley. O violão percussivo: levantamento, catalogação, classificação e sistematização de recursos instrumentais. In: SIM! SIMPÓSIO INTERNACIONAL DE VIOLÃO, 1., 2017, Belo Horizonte. Anais... Belo Horizonte, UFMG/Unimontes/UFSJ, 2017. p. 55-69.

INDA, Amilcar Rodriguez. Varias posibilidades sonoras de la guitarra en la musica contemporánea. Florida, Uruguay: Efecé,1984.

KAFEJIAN, Sérgio; FERRAZ, Sílvio. O uso das técnicas estendidas e o conceito de instrumento musical em Helmut Lachenmann. Musica Theorica, v. 2, n. 1 p. 198-214, 2017.

KREUTZ, Thiago de Campos. A música para violão solo de Edino Krieger: um estudo do idiomatismo técnico-instrumental e processos composicionais. Dissertação (Mestrado em Música) - Escola de Música e Artes Cênicas, Universidade Federal de Goiás, Goiânia, 2014.

LEVI FERNANDES, Stanley. Gravação de Eclusas. Compositor: Silvio Ferraz. Violão solista: Stanley Levi. Cuiabá, 2018. Disponível em: https://www.youtube.com/watch?v=iFZf_tyoQds\&feature=youtu.be. Acesso em: 25 maio 2019.

LEVI FERNANDES, Stanley. Recursos Percussivos no Violão de Concerto. In: SIM! SIMPÓSIO INTERNACIONAL DE VIOLÃO, 1., 2017, Belo Horizonte. Anais... Belo Horizonte, UFMG/Unimontes/UFSJ, 2017. p. 24-26.

LEVI FERNANDES, Stanley; BRAGA, Cristiano; CARPENEDO, Amanda. Violão Percussivo: estado da arte, trajetória e perspectivas. Mesa Redonda realizada na Escola de Música, Universidade do Estado de Minas Gerais, 20 mar. 2021. Transcrição de Ledice Fernandes Weiss. Material audiovisual e transcrição não publicados. 
LIDOV, David. Emotive Gesture in Music and its Contraries. In: GODØY, Rolf Inge; LEMAN, Marc (Org.). Musical gestures: sound, movement, and meaning. New York, London: Routledge Taylor \& Francis Group. 2006. p. 24-44.

LUNN, Robert Allan. Extended Techniques for the Classical Guitar: A Guide for Composers. Tese (Doutorado) - The Ohio State University, Ohio, 2010.

MACIEL, Michel Barboza. Ritmata de Edino Krieger: uma reflexão sobre processos vanguardistas na literatura do violão brasileiro. Dissertação (Mestrado em Música) - Escola de Música, Universidade Federal de Minas Gerais, Belo Horizonte, 2010.

MURRAY VASCONCELlOS, Daniel; FERRAZ, Silvio. Sobre Ladainha. [s.n.], 2009. Disponível em: https://www.danielmurray.com.br/universossonoros/silvio ferraz.html. Acesso em: 11 maio 2021.

MURRAY VASCONCELlOS, Daniel. Gravação de Ladainha. Compositor: Silvio Ferraz. Violão solista: Daniel Murray. Campinas, 14 maio 2008. Disponível em: https://www.youtube.com/watch?v=2hSBJrWyWQ4. Acesso em: 30 mar. 2019.

PEREIRA, Sayonara. Pensando a dança dançadamente: ou como falar uma linguagem mais unânime para diferentes "tribos". In: CONGRESSO DE PESQUISA E PÓS-GRADUAÇÃO EM ARTES CÊNICAS, 6., 2010, Campinas. Anais... Campinas, ABRACE, 2010.

ROBERT, Jean Pierre. Modes de jeu de la contrebasse Paris: JP Robert, 1992.

ROMÃO, Paulo César Veríssimo. Técnicas estendidas: reflexões e aplicações ao violão. In: CONGRESSO DO SIMPOM, 2., 2012, Rio de Janeiro. Anais... Rio de Janeiro, 2012. p. 12931302. Disponível em: http://www.seer.unirio.br/index.php/simpom/article/view/2556/1885. Acesso em: 30 mar. 2019.

TAPPING. Wikipédia: l'encyclopédie libre. [s.1.]: [s.n]. Disponível em: https://fr.wikipedia.org/wiki/Tapping. Acesso em: 30 mar. 2019.

VASCONCELLOS, Daniel Murray. Técnicas estendidas para violão: hibridização e parametrização de maneiras de tocar. Dissertação (Mestrado em Música) - Universidade Estadual de Campinas, Campinas, 2013.

TEIXEIRA DA SILVA, William; FERRAZ, Silvio. A adesão ao discurso musical contemporâneo: uma abordagem retórica. Revista Trivium, v. 7, n. 1, 2015a, p.117-126. Disponível em: $\quad$ http://pepsic.bvsalud.org/scielo.php?script=sci arttext\&pid=S217648912015000100011. Acesso em: 30 mar. 2019.

TEIXEIRA DA SILVA, William; FERRAZ, Silvio. Técnica estendida e escrita polifônica em Luciano Berio: Sequenza XIV. In: MENEZES, Flo (Org.) Luciano Berio: legado e atualidade. São Paulo: Editora da Unesp Digital, 2015b, p. 121-139.

WEISS, Ledice Fernandes. Compreender a técnica estendida no violão: um elogio ao gesto. OPUS, Brasil, v. 25, n. 3, p. 224-255, nov. 2019. Disponível em: https://www.anppom.com.br/revista/index.php/opus/article/view/opus2019c2511. Acesso em: 28 maio 2020. 
WEISS, Ledice Fernandes; FERRAZ, Silvio. Entrevista sobre composição Ladainha e Eclusas. [s.n.], 2021.

WEISS, Ledice Fernandes; FERRAZ, Silvio. Relações transversais entre compositor e performer: os exemplos de Ladainha e Eclusas de Silvio Ferraz. In: ENCONTRO INTERNACIONAL DE TEORIA E ANÁLISE MUSICAL, 5., 2019, Campinas. Anais... Campinas, Universidade Estadual de Campinas, 2019. p. 365-374. Disponível em: https://eitam5.nics.unicamp.br/wpcontent/uploads/2020/12/EITAM5-paper_26_WeissL_FerrazS-pp_365-374.pdf. Acesso em: 18 jun. 2021. 
